STATE OF ALASKA

Keith H. Miller - Governor

DEPARTMENT OF NATURAL RESOURCES

Thomas E. Kelly - Commissioner

DIVISION OF MINES AND GEOLOGY

James A. Williams - Director

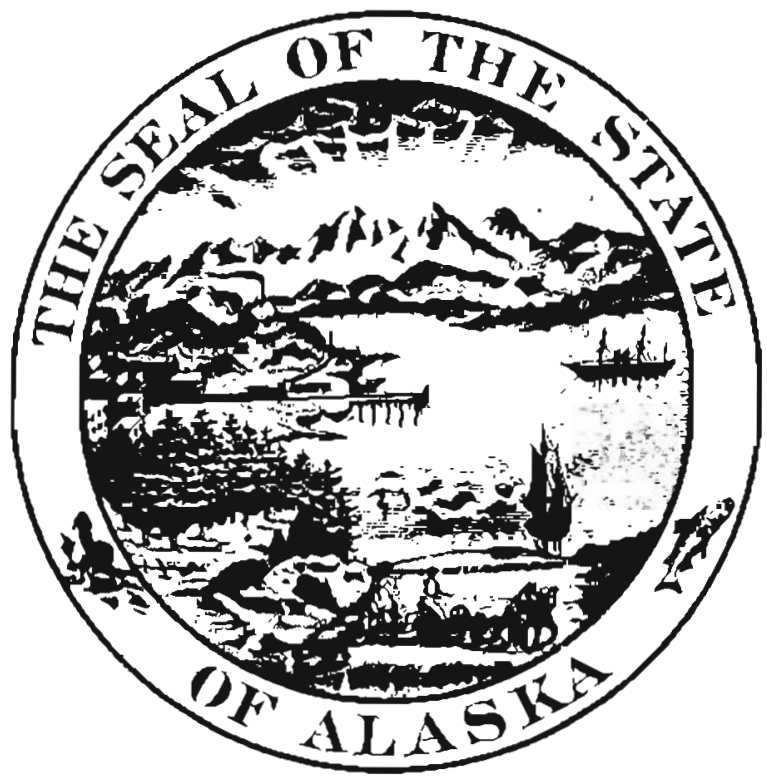

GEOLOGIC REPORT NO. 38

Uranium in Alaska

By

Gilbert R. Eakins

College, Alaska

May 1969 
GENERAL GEOLOGY OF URANIUM ........................... 4

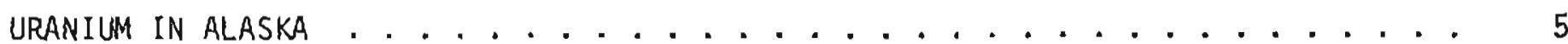

Bokan Mountain uranium-thorium area .................. . . . . 6

Hyder mining district, southeastern Alaska . . . . . . . . . . . . . . 6

Salmon Bay area, southeastern Alaska.... . . . . . . . . . . . . 7

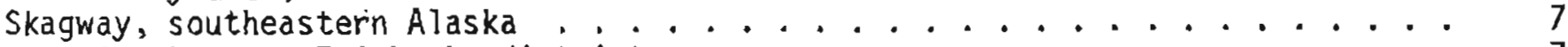

Hope Creek area, Fairbanks district. . . . . . . . . . . . . . . . 7

Brooks Mountain area, Seward Peninsula . . . . . . . . . . . . . . . . 8

Ear Mountain area, Seward Peninsula . . . . . . . . . . . . . . . . 8

Locality near Rampart, on the Yukon River . . . . . . . . . . . . . . . . 9

Selawik Basin region, western Alaska ................... 9

other areas of interest....................... 9

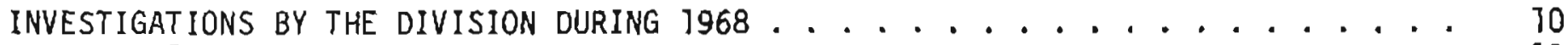

General Statement.................... . . . 10

Healy coal district......................... . . . . . . . 12

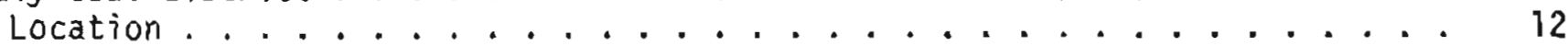

Purpose .. . . . . . . . . . . . . . . . . . . . . . . 12

Geology . . . . . . . . . . . . . . . . . . . . . . 12

Results . . . . . . . . . . . . . . . . . . 13

Eagle area and highway traverses, Fairbanks to Eagle ............ 13

Location....................... . . . . 13

Purpose .. . . . . . . . . . . . . . . . . . . 13

Geology ............................... . . . 13

Results . . . . . . . . . . . . . . ........... 13

Cantwell-Mount Mckin iey National Park areas and locations adjacent to

the Richardson and Denali Highways . . . . . . . . . . . . . . . 14

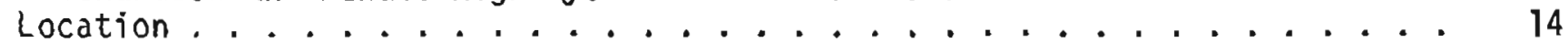

Purpose . . . . . . . . . . . . . . . . . . . . . 15

Geology . . . . . . . . . . . . . . . . . . . 15

Results . . . . . . . . . . . . . . . . . . . 15

Alaska Peninsula areas . . . . . . . . . . . . . . . . . . 16

Location......................... . . . . . . . 16

Purpose ......................... . . . . . 15

Geology . . . . . . . . . . . . . . . . . . . . . 17

Results . . . . . . . . . . . . . . . . . . . . . 17

Matanuska valley coal district . . . . . . . . . . . . . . . . . 18

CONCLUSIONS . . . . . . . . . . . . . . . . . . . . . . . . 18

TABLE SUMMARIZING INVESTIGATIONS FOR URANIUM IN ALASKA . . . . . . . . . . . . . 19

REFERENCES CITED . . . . . . . . . . . . . . . . . . . . . 47

\section{ILLUSTRATIONS}

Figure 1 Correlation of Jertiary rocks of Alaska ............... . 11

2 Index to $1: 250,000$ quadrangle maps ............... 21

3 Map of Alaska showing locations of radioactivity investigations . . . Pocket (East half and West ha]f) 


GEOLOGIC REPORT NO. 38

\title{
URANIUM IN ALASKA
}

By Gilbert R. Eakins

\author{
A B S T R A C T
}

The geology of Alaska is favorable for uranium deposits, and large areas remain untested. This report has been prepared to assist those interested in the search for uranium in the State. All radioactive mineral investigations conducted by Federal and State agencies in Alaska are summarized in a table form. The regions from which the richest and largest numbers of radioactive samples have been collected are southeastern Alaska and the Seward Peninsula. Particular areas dtscussed are (3) the Bokan Mountain uranium-thorium area, including the Ross-Adams mine, (2) the Hyder mining district, (3) Skagway, (4) Hope Creek in the Fairbanks district, $(5)$ the Brooks Mountain and Ear Mountain areas on the Seward Peninsula, and (6) the Selawik Basin and vicinity in western Alaska. Other areas belfeved by the writer to warrant investigation are the Ketchikan, Petersburg, and Wrangell districts of southeastern Alaska and the Ogilvie Mountains near the Canadian border north of the Yukon River. Phosphate beds in the northern foothills of the Brooks Range contain low grade uranium.

The report also summarizes recent investigations of Tertiary sandstones by the writer during the summer of 1968 . The general areas visited are the Healy coal district, the Eagle area, the Cantwel]-Mount McKinley National Park areas and localfties near the middle of the Alaska Peninsula. Maximum radfoactivity readings of five times background were obtained on the ground. None were sufficiently high to indicate potential ore, but permafrost, meteoric water, and steep dips of many of the Tertiary rocks may have caused near-surface conditions which make uranium detection difficult.

Many of the uranium showings in Alaska have not been tested at depth, and diamond drilling is recommended in some areas. Aerial radiometric surveys and geochemical sampling of stream sediments and soils are methods applicable to uranium prospecting in large parts of the State. The Division of Mines and Geology plans to test geochemical, geobotanical, and aerial survey methods applfcable to uranium prospecting during the sumer of 1969.

\section{N T R O D U C T I O N}

The first uranium rush began shortly after Wor $1 d$ War II when the U. S. Government offered a discovery bonus and a guaranteed price for uranium production. This boom lasted untif 1958 when the Atomic Energy Commission announced that the reserves found up to that time were more than adequate to meet the nation's needs. Exploration came to a standstill, and AEC purchases were then limited to a few "stretch out" contracts, which were extensions granted to assist certain mining operations until 1970. However, all predictions of future uranium requirements had greatly underestimated the rate of growth of the nuclear power industry. The AEC recently stated that in 1965 less than one percent of the electrical generating capacity of the country was nuclear. It estimated that nuclear power plants will supply 23 to 30 percent of our electricity by 1980 and as much as 50 percent by the year 2000 . The near-future uranium needs therefore are believed to be far greater than the known supply available at current prices. While the present price of $\$ 8.00$ per pound of $\mathrm{U}_{3} \mathrm{O}_{8}$ may prevail for some time, many men within the industry feel that the price will increase so that lower grade ores or higher cost reserves can be used to help satisfy the anticipated demand for more nuclear fuel. The immediate result has been a second uranium boom.

The main difference between the early exploration programs and those being conducted today is in size and sophistication. The easily located deposits, especially in accessible areas, 
have been mostly found by individual prospectors and small organizations who swarmed over the country in the $1940^{\prime} \mathrm{s}$ and $1950^{\prime} \mathrm{s}$. Today exploration 15 , for the most part, in the hands of large companies geared to large scale and expensive programs which are required to locate the deeper and more obscure deposits. Exploration and development drilling for uranium reached a new high of 70.8 millton feet during 1967 . A total of $\$ 500$ million probably will be spent on uranium exploration between now and 1980.

Alaska should be considered a potential source of major quantities of uranium. The RossAdams mine on Prince of Wales Is land already has produced high-grade uranium ore. When the great size and complex geology of the State are considered, it seems inevitable that important concentrations of uranium eventually will be found here. The area involved is equivalent to the combined areas of Arizona, Colorado, Idaho, New Mexico, Utah, and Wyoming. Furthermore, with much of the State relatively unexplored, it is likely that important discoveries still can be made by individual prospectors and small companies, in spite of the activities of larger organizations.

This report has been prepared to encourage and guide uranium explorations within the State. All investigations for radioactive minera 3 s both by the Federal Government and Alaska, as a Territory and as a State, have been located on the accompanying map and referenced. There is no way to include the work done by private companies or individuals, but old assay reports on file at the State Division of Mines and Geology include a number of uranium assays on samples submitted by prospectors which are significantiy high to stir interest.

While the number of localities that have been visited and the extent of traverses as shown on the map may suggest that there has been considerable exploration, the actual area covered by radiometric ground surveys is very small in relation to the entire State. During the late 1940's and 1950's, the U. S. Geological Survey conducted a number of radiometric surveys in Alaska for the AEC. These investigations were directed primarily at (1) evaluating known lode mines and prospects for uranium and (2) testing of concentrated stream sediment samples in hopes of locating source rocks which might be abnormally radioactive. These studies revealed a number of radioactive anomalies, but no production has yet resulted The localities investigated and the airborne anomalies detected are indicated on the accompanying map. Additional investigations by the writer during the summer of 1968 are also indicated on the map. These are discussed in a separate section of this report.

$$
\text { GENERAL GEOLOGY OF URAN } 1 \text { U M }
$$

Hundreds of reports, books, and papers on the various uranium deposits of the world have been published during the last twenty years. Still it is very difficult to make any general statements regarding radioactive ores. Because of the solubility and mobility of uranium, its ores have been found to some extent in all types of rocks and of nearly every geologic age and environment. While uranium is widely dispersed, economic concentrations are rare. The origin, age, geochemistry, and structural controls of known deposits are stfll subjects of disagreement and speculation. However, certain mineral associations and sedimentary environments occur in a sufficient number of cases to serve as useful guides (but not rules) in prospecting for new deposits. The geology of uranium and praspecting methods wil] be briefly outlined here, but those who are preparing to explore are also referred to bibliographies published by the AEC and the U. S. Geologica] Survey.

Uranium may be found either as primary deposits in veins, or as secondary deposits in bedded sedimentary rocks. The principal source of uranium is acidic igneous rocks, such as granite, syenite, pegmatites, or rhyolitic volcanic ash beds. In these rocks may be found uranium minerals, such as uraninite, or trace amounts of uranium contained in the accessory minerals such as zircon, allanite, monazite, xenotime, and sphene. The deposits of primary uranium commonly are associated with silver, copper, thorium, and cobalt and appear most often in zones marginal to base metal ore districts. The most universal gangue 
minerals of the vein deposits seem to be hematite, purple fluorite, and red jasperoid. These gangue minerals should be partlcularly useful as "indicators". The basic or darkcolored igneous rocks are very low in uranium content. While the ores are generally believed to be related to nearby granitic rocks, veins or dikes containing uranium may cut any type of country rock.

Even though the richest uranium ores are in a relatively few known vein deposits, over 90 percent of the world's reserves are in sedimentary rocks -- sandstones and conglomerates of continental origin. Essential conditions to the formation of bedded or sedimentary-type uranium deposits are (1) the presence of continental sediments, mainly siltstones, arkosic sandstones, or conglomerates, (2) a granitic or volcanic source which by weathering or leaching has produced uranium-bearing solutions or sediments, (3) a reducing chemical environment to cause precipitation of the uranium from acidic transporting waters, and (4) entrapment so that there will be no further leaching by meteoric waters. Reducing conditions are created by the presence of carbonaceous plant material or hydrogen sulfide. Pyrite is always present in beds containing unoxidized uranium. The most favorable criterion are continental sandstones deposited by ancient streams in foreland regions. Bedded deposits consist of fine-grained uranium minerals that f 111 pore spaces or replace plant fossils and cementing material in the host rock. Reducing enviroments are sometimes detected by alteration, or "bleaching", of the enclosing sediments. Bleached sandstones are light colored (gray, green, buff) in comparison with the unbleached (red, brown) oxidized rocks.

The primary uranium minerals, such as uraninite, are generally dark-colored, brown to black, and are found either in veins or pegmaite dikes or dispersed between the grains of sedimentary rocks. When uranium minerals become oxtdized by weathering at or near the surface, secondary or oxidized minerals, such as carnotite, are formed. These are frequently bright yellow, green, brown, and reddish brown. However, because of the cold, damp climate in Alaska, the bright colored, soluble, secondary minerals are less likely to be found here than they are in the warm, dry regions.

The greatest part of the known uranium reserves in the United States are in sandstones and conglomerates of Triassic and Jurassic ages in the Colorado Plateau region and in sediments in Tertiary basins in Wyoning. Outside the U. S. most of the free world's uranium reserves are in Precambrian conglomerates as in the Elliot Lake (BTind River) district in Ontario, Canada, and at Witswatersrand, South Africa. The average grade of the ores mined in the United States is 0.20 to 0.25 percent. The grades of the vast Canadian and South African deposits are somewhat lower.

Thorium is a radioactive mineral which is fairly widespread and frequently associated with uranium. At present thorium is not in demand for nuclear fuel, but it may become so. If found in quantity it should be considered potentially important. Radiations from thorium affect a geiger counter or scintillometer in the same manner as uranium. Because of this difficulty, modern multi-channel spectrometer-type scintillometers which can distinguish between uranium and thorium radiation are useful in prospecting.

\section{URA I I M I N ALASKA}

The accompanying table and map sumarize available data concerning uranium in Alaska. It is not possible at this time to outline uranium provinces as has been done for the Colorado Plateau, but uranium and thorjum have been produced from the Bokan Mountain area near Kendrick Bay on the southeastern part of Prince of Wales Island in Southeastern Alaska. This area and others where pronounced radioactive anomalies have been found are circled on the map. In addition to the comments in the table these particular areas are discussed briefly in the following sections. The information in these sections is taken from U. S. Geological Survey reports. Location numbers refer to locations on the map. 


\section{BOKAN MOUNTAIN URANIUM-THORIUM AREA}

\section{(Location 1)}

The original uranium discovery was made in 1955 by Don Ross and Kelly Adarns using an afrborne geiger counter. The known uranium-thorium mineralization is centered on and around a small, late-stage granite stock believed to be Tertiary in age, which intruded an older Paleozoic pluton composed of quartz monzonite and granodiorite. Numerous small radioactive deposits have been found within a 71-square-mile area. Deposits not directly related to the granite stock have been found in aplite and pegmatite dikes. The dikes are up to 1000 feet. long and 10 feet wide and are potentially important because of their uranium, thorium, zirconium, and rare earth contents. The radioactive minerals are principally orimary types and consist of uranothorite, uranoan thorianite and uraninite which occur as scattered grains throughout the granite and in numerous thin veinlets. Secondary minerals are rare but some of the ore, possibly autuntte, fluoresces brightly under an ultraviolet light. The chief gangue minerals are hematite, calcite, fluorite, and quartz.

The ore at the Ross-Adams mine does not fit into any of the "typical" types or uranium vein deposits, such as those classed as associates of the njckel-cobalt-silver group, the silica-iron-lead group, or the iron-titanium group. The ore body is an irregular concentration roughly $50 \times 50 \times 400$ feet. A large portion of the ore averages over one percent $\mathrm{U}_{3} \mathrm{O}_{8}$, and pods contain up to three percent $\mathrm{U}_{3} \mathrm{O}_{8}$. There are no important metallic sulfide: associated with the ore, and there is little evidence of structural control. However, there are many copper and gold prospects in the region.

Kendrick Bay Mining Co., a subsidiary of Standard Metals Corp., has stated that the Bokan Mountain property produced approximately 39,000 tons of ore averaging approximately 1.0 percent $\mathrm{U}_{3} \mathrm{O}_{8}$ between 1957 and 1964 . The mine has been inactfve since that time, but it was recently announced that the Kendrick Bay Mining Company in a joint venture with the Newmont Mining Company plans to reopen the property. It is possible that new ore will be located at depth.

The Bokan Mountain area and the numerous radioactive anomalies at other localities in Southeastern Alaska make this the most promising part of the State for uranium prospecting.

\section{HYDER MINING DISTRICT, SOLTHEASTERN ALASKA}

\section{(Location 16)}

The Hyder district is at the head of Portland Canal near the Alaska-British Columbia border. The area is highly mineralized and includes a number of properties containing marginal deposits of gold, silver, copper, lead, zinc, and tungsten. Radioactive material, which apparently is uranium, is widely distributed. Mesozolc Coast Range granodiorite and quartz monzonite are intrusive into Jurassic greenstones, tuffs, graywackes, argillite, and quartzite. Most of the radioactive minerals are associated with sulfides, but some form thin secondary coatings on fracture surfaces. The we]1-known Premier mine is just across the border in British Columbia.

Uranium investigations have been concentrated on the Mountain View property, about five miles north of Hyder, where assays as much as 0.049 percent equivalent uranium were obtained. A sample of pitchblende, reportedly from the Canyon vein, assayed 0.7 percent equivalent uranium oxide, but this material was not found during a later U. S. Geological Survey examination. 
The high radioactivity at several locations and the favorable mineral assemblage may be sufficjent basis for more intensive exploration in this district. Of additional interest is the presence of radioactive minerals at 30 or more metallic mineral localities in nearby British Columbia, all of which are west of the Rocky Mountain trench.

SALMON BAY AREA, SOUTHEASTERN ALASKA

(Location 21)

Significant radioactivity extends for eight miles along the northeastern coast of Prince of Wales Island. The radioactive material is in short irregular carbonate-hematite veins which cut graywacke of silurian age. Many basic dikes also cut the country rock. The highest value obtained was from a grab sample collected by a prospector which assayed 0.13 percent equivalent uranium or 0.64 percent equivalent thorium. Seven channe] samples covering 100 feet along one vein averaged 0.034 percent uraniun or 0.16 percent equivalent thorium. The veins are generally less than one foot wide and 300 feet long. Some nonradioactive veins contain high-grade rare-earth oxides. It appears that the radioactivity in the area is due mainly to thorium.

The widespread presence of radioactive minerals in the northern part of Prince of Wales Island and the high grade uranium ore at Bokan Mountain on the south end suggest the intervening area is worth close examination.

SKAGWAY, SOUTHEASTERN ALASKA

(Location 42-A)

A uranium prospect was discovered in 1956 almost in the town of Skagway. The deposit is in a bluff about 250 feet directly above railroad tracks and large oil storage tanks. Bedrock consists of altered rhyolite(?), quartz diorite, and andesite dikes. Large faults cut the quartz diorite. Uranium minerals with iron staining are present along a steeply dipping fracture in the rhyolite(?). No other ore minerals or vein material, except purple fluorite, have been reported.

The most radioactive sample analyzed by the U. S. Geological Survey was a small pod of clay, which assayed 0.72 percent equivalent uranfum and 1.2 percent uranium. Other samples of the rhyolite contain up to 0.22 percent equivalent uranium. No ore has been produced, but the geology is favorable and additional prospecting is planned.

HOPE CREEK AREA, FAIRBANKS DISTRICT

(Location 81)

The Fairbanks district is not considered particularly favorable for uranium, but a sample of brecciated granite float near a small body of intrusive granite about 10 miles north of the Steese Highway and about 80 miles northeast of Fairbanks contained 0.055 percent equivalent uranium. The sample contained hematite-goethite veinlets. The uranium minerals were not jdentified. Twenty-one samples of the granite collected by the U. S. Geological Survey contained between 0.001 and 0.004 percent equivalent uranium. Quartz, pyrite, and fluorite have been reported in veins cutting the Birch Creek schist near the granite. The 0.055 percent sample and the associated hematite and purple fluorite may be sufficient justification for uranium prospecting. 
BROOKS MOUNTAIN AREA, SEHARD PENINSULA

(Location 156)

The U. S. Geological Survey has conducted rather extensive examinations of a metazeunerite occurrence at Brooks Mountain. Metazeunerite [Cu(U02)2(As04): 8H20] is a hydrous copper-uranium arsenate containing 46.4 percent uranium. The following description of the radioactive deposit is the abstract from U. S. Geological Survey circular 214, "The Occurrence of Zeunerite at Brooks Mountain, Seward Peninsula, Alaska", by Walter S. West and Max G. White.

Zeunerite occurs near the surface of a granite stock on the southwest flank of Brooks Mountain, Alaska. The largest deposit is at the Foggy Day prospect. Zeunerite is disseminated in hematite which partially or totaliy fills openings and vugs in a highly oxidized lens-shaped body of pegmatitic granite and, to a minor extent, in openings and cracks in the weathered granite enclosing the lens. Although a few specfmens from the pegmatitic lens contain as high as 2.1 percent equivalent uranium, the average content of the lens rock is between 0.1 and 0.2 percent equivalent uranium and that of both the lens material and the surrounding zeunerite-bearing granite is about 0.07 percent equivalent uranium. A smaller concentration of zeunerite occurs as surface coatings on a few of the quartz-tourmaline veins that occupy joint fractures in the granite on Tourmaline No. 2 claim and in two samples from other sites near the Foggy Day prospect. The zeunerite at these three localities is probably related in source to the Tourmaline No. 2 clajm and Foggy Day prospect deposits.

Although no primary uranium minerals were found, it is possible that a primary mineral zone may occur below the zone of oxidation at the Foggy Day prospect.

It has been recommended that further exploration be done by djamond drilling directed at locating a possible primary uranium source at depth below the secondary zeunerite.

EAR MOUNTAIN, SEWARD PENINSULA

(Location 159)

Ear Mountain is located in the northwestern part of the Seward Peninsula about 10 miles inland from the Bering Sea. The core of the mountain is a granite stock two miles in diameter penetrating Ordovician(?) schistose limestone. The area has been much prospected for placer and lode tin. Mafic dikes cut both the granite and limestone. Quartz veins and small pegmatite dikes are common. Small amounts of copper, lead, zinc, tin, fluorite, and traces of gold and silver have been reported from the winfield mine shaft.

Radioactivity detected in some 600 placer concentrates collected by the U. S. Geological Survey show the presence of radjoactive minerals in the area. The highest assay obtained from concentrates was 1.0 percent equivalent uranium. Radioactivity of the bedrock is mostly in the margins of the granite and principally in tourmaline and quartz veins, especially where there is hematite. The most radioactive piece of red ore contained 0.182 percent equivalent uranium. The primary radioactive mineral in the red ore has not been identified, but the secondary minerals metazeunerite and metatorbernite were noted. Thorium is probably present.

Commercial uranium has not been found, but since much of the area is covered, stripping might reveal more extensive deposits. 


\section{LOCALITY NEAR RAMPART, ON THE YUKON RIVER}

(Location 140)

Tertiary conglomerates have yielded up to 0.014 percent equivalent uranium a few miles upstream from Rampart. This is the highest radioactive assay reported from Tertiary rocks in Alaska and suggests that Tertiary sediments could be a host for uranium ores in this region.

\section{SELAWIK BASIN REGION, WESTERN ALASKA \\ (Locations $166,167,168,170,171$ )}

Several radioactive anomalies have been detected on the ground and from the air over a large area which includes the north side of the Kobuk River Valley, the hills south of Selawik Lake, and the Zane Hills. These anomalies suggest that this region could contain ore-grade uranium. Granitic rocks, tuffs, and vein type sulfide ores known in the region could be sources for either lode or sedimentary uranium. In addition to the comments in the table these anomalies are reviewed here.

Location 171 -- A sample containing columbite and tantalite found near Kiana may indicate possible uranium associations. Slight radioactivity of carbonaceous beds in the same area may be significant.

Location 170 -- Radioactivity in the rich copper deposits at Bornite near Kobuk has been noted. Sphalerite assoclated with the ore has been reported to contain 0.013 percent uranium. Sooty pitchblende has been encountered in drill cores and radioactive minerals recognized on the surface (Runnells, $0.0 .$, 1964$, p. 69,78$)$.

Location 168 - Radioactivity five to ten times background was found in the borders of the Zane Hills piuton in the vicinity of Caribou Mountain. A sample of the quartz monzonite assayed $0.002 \%$ uranjum.

Location 167 -- Radioactive trachyte containing $0.005 \%$ lead and $0.015 \%$ zirconfum was sampled at a small intrusive body about three miles south of Selawik Lake.

Location 166 -- Airborne radiometric measurements along a northeast flight line from Kiwalik on Eschscholtz Bay to a point a few miles south of Gabolio ranged from 100 to 1600 counts per minute. The highest counts, from 800 to 1600 , were detected over granite southeast of Reindeer Station.

\section{OTHER AREAS OF INTEREST}

The following regions have not been investigated. They are mentioned because they have mineral assemblages and rock types with a better-than-average possibility for uranium deposits.

1) The Ketchikan, Petersburg, and Wrangell districts of southeastern Alaska contain silver, lead, platinum, molybdenum, fluorite, and other minerals. These areas do not seen to have been adequately prospected for uranium. The geology is favorable.

2) A region north of the Yukon River in the Ogilvie Mountains contains Precambrian, Paleozoic, Mesozoic, and Tertiary rocks. The Precambrian Tindir group contains red beds of hematitic dolomite, shale, flint, tuff, and lava, with a red basal conglomerate. These beds are reported to be similar both in lithologies and age to the rocks at 
Great Slave Lake, Northwest Territorles, Canada, where samples containing 0.17 percent thorium oxide and 0.006 percent uranfum have been obtalned. The large reserves of uranium in Canada are mostly in Precambrian conglomerates. A brief investigation by the U. S. Geological Survey in the Eagle-Nation area did not reveal radioactive anomalies, but work was 1 imited to traverses along the Yukon and Tatonduk Rivers.

3) Phosphate rock frequently contains uranium in quantities considerably above the average for sedimentary rocks. Extensive deposits of phosphate rock are present in the foothills north of the Brooks Range. Equivalent uranium assays have been reported up to 0.021 percent, and assays between 0.005 and 0.015 percent are common. The highest uranium assays are obtained where the $\mathrm{P}_{2} \mathrm{O}_{5}$ content is greatest. Byproduct uranium could be a factor in making these deposits economic at some future date.

4) A sample of uraniferous 1 imestone containing 0.6 percent uranium oxide was submitted to the U. S. Geological Survey in 1951 (TEI 577, p. 78, 79, 86). The radioactive mineral was identified as metatyuyamunite and was disseminated throughout the limestone and on bedding surfaces. The sample was reported to have been found by an Indian somewhere in the vicinity of Nikolai Creek about 17 miles northwest of Tyonek, Tyonek quadrangle, in southwestern Alaska. The Jocation was never verified and the source of the sample remains very uncertain. While many rumored or unverified assays and sample locations have been deliberately omitted from this study, the geology of this area, in conjunction with the reported sample, seems interesting and to warrant investigation. In addition to the one sample submitted, natives in the area have mentioned "similar yellow rocks" from Eocene clastic coal-bearing beds and volcanics known to be present several miles northwest of the reported location of the radioactive limestone.

A uranium prospect on the north side of Shirley Lake (Location No. 125) about 75 miles northwest of Tyonek Village may or may not be related to the sample mentioned above. At Shirley Lake anomalous radioactivity was found in coatings along small, shallow joints cutting tuff and tuff breccia. The maximum assay obtained by the U. S. Geological Survey was $0.027 \%$ uranium, but a prospector reported that one sample from this area assayed $0.29 \%$ uranium.

\section{INVESTIGATIONS BY THE DIVISION $D U R I N G \quad 1968$}

\section{GENERAL STATEMENT}

Large uranium reserves have been discovered in the Tertiary sandstones in wyoming, and many deposits are known to exist in sediments that have accumulated in intermontane basins. These areas are receiving much attention, and ore is still being discovered. Interest, therefore, is directed to Tertiary basins containing continental sands and conglomerates in other regions in the hope of locating similar ores.

A preTiminary investigation was undertaken by the State Division of Mines and Geology to ascertain the best approach to the investigation of Alaska's uranium potential. Ouring the surmer of 1968 the writer, assisted by Michae? Hoge, spent nine weeks examining sediments in Alaska. The primary aim was to determine if continental sandstones and conglomerates of Cretaceous and Tertiary ages contained abnormal radioactivity. In spite of the relatively recent geologic age of the Tertiary Period, late mountain building in Alaska has resulted in intense uplift and much faulting of rocks of this age. 
Dips of 20 to 30 degrees are common and occasionally dips up to 70 degrees are observed. Plant fossils give evidence of a temperate to subtropical climate during Tertiary time.

The principal areas examined were (1) the Healy coal mining district in central Alaska, (2) the Eagle area, including traverses along the Yukon River, in east-central Alaska, (3) the Cantwell-Mckinley Park area, including the Dunkle coal mine and Silver King mine on the west fork of the Chulitna River in central Alaska, and (4) the Port Moller, Chignik areas and Unga and Popof $[5$ lands in the Alaska Peninsula region.

A four-channel spectrometer-type scintillometer ordered by the Division of Mines and Geology for the work was not recefved until the field season was over. 01d Model DR 299 Detectron Nucliometers were used most of the time. These detectors contain a bank of twenty-five small geiger tubes and are sufficiently sensitive for surveys on foot or from a vehicle. A Model 177 B "Scintillator" manufactured by Precision Radiation Instruments, Inc., was avajlable for part of the summer. Frequent failure of all instruments due to excessive moisture was a problem in spite of the special covers used for their protection.

HEALY COAL DISTRICT

(Location 78)

Location

This area lies along Healy River, a tributary of the Nenana River, in the Healy D-4 quadrangle. Healy townsite is opposite the mouth of Healy River on the Nenana River. It is accessible from Fairbanks by Highway 3.

Purpose

The presence of Tertiary arkosic sandstones of continental origin with much carbonaceous material suggests a similarity to the Tertiary rocks containing uranium in the western states. The writer spent one week in the area examining the sediments. Tertiary coalbearing beds occur in a number of areas along the north flank of the Alaska Range, but those near Healy are well exposed and.easily accessible. Incidental examinations of nearby exposures of Birch Creek schist, Totatlanika schist and Nenana gravels were also made.

\section{Geology}

A syncline in the foothills along the north flank of the Alaska Range contains Tertiary sediments for a distance of twelve miles along the Healy Creek valley. This area is described by Barnes, Wahrhaftig. Hickcox, Freedman and Hopkins (1951). The valley and the syncline are bounded by ridges of Birch Creek schist. Eocene coal-bearing beds as much as 2,000 feet thick lie unconformably on the schist. They extend along strike approximately east-west for twelve miles and between one and two miles at right angles to the structure. The coal-bearing sequence contains shales, sandstones, claystones, siltstones and a number of subbituminous coal beds. They dip approximateiy 35 degrees north, but are locally overturned. The sandstones are soft, easily eroded, partly arkosic, and commoniy contain stringers of coaly material. Some platy beds of shale and claystone contain abundant leaf imprints. Coarse, unconsolidated Nenana gravels of Tertiary age overlie the coal sequence.

Open pit coal mining is conducted the year around in the valley. Individual coal beds range from a few inches to 40 feet in thickness. 
Results

The area was crossed at several points by walking up gulleys so that each bed in the coal-bearing sequence was tested for radioactivity, and foot traverses were made along the entire 12-mile-long area containing the Tertiary outcrops. The maximum radioactivity in sandstones, shales, and Birch Creek schist was about $0.04 \mathrm{Mr} / \mathrm{Hr}$ or three times the normal background. At some points, the Birch Creek schist gave slightly higher counts than any of the Tertiary beds. The schist has a high mica content, which may be the source of radioactivity.

While the Tertiary lithology and the abundance of carbonaceous material seem favorable for uranium deposition, the movement of meteoric waters and the disturbed positions of the beds probably make its near-surface retention and detection difficult. Results of the study indicate that the sediments at Healy are not likely to contain significant amounts of uranium or thorium.

EAGLE AREA AND HIGHWAY TRAVERSES, FAIRBANXS TO EAGLE

(Locations $63,73,74,75,87,88,89$ )

Location

The village of Eagle is on the south bank of the Yukon River in the Eagle D-1 quadrangle, about five miles west of the Canadian border. Localities and outcrops adjacent to the highways between Fairbanks and Eagle and along the Yukon River from the border to a point 20 miles west of Eagle were examined. In addition, Tertiary beds along American and Mission Creeks south and west of Eagle were studied.

Purpose

The primary objective was the examination of the Tertiary sandstones in the Area. The testing of the Pennsylvanian Nation River conglomerate and sandstones and the Mesozoic granites was a secondary purpose.

Geology

Mertie (1942) describes a belt of Tertiary sediments trending northwest along the south side of the Yukon River from the Canadian border almost to Circle Hot Springs, a tota] distance of almost 100 miles. The belt varies in width from two to ten miles. It is widest south of Nation. A granite batholith parallels the Tertiary rocks a few miles to the south. The granite could be a source of radioactive minerals. Since streams flow north to the Tertiary sediments this may be a favorable condition for their redeposition. A variety of $\mathrm{Paleozoic}$ and Mesozoic sediments crop out along the Yukon in the area visited.

Results

Radioactivity measurements between 0.03 and $0.05 \mathrm{Mr} / \mathrm{Hr}$, or two and four times background, were made at a number of outcrops. These locations and some other points of interest are mentioned below.

Location 63 -- Granite exposed in a road cut at Mile Post 1303 on the Alaska Highway just east of the bridge crossing the Tanana River gave a counter reading of $0.04 \mathrm{Mr} / \mathrm{Hr}$, or three times background. 
Location 73 -- A broad area of acidic intrusives and flow rocks which gave unusually high background readings extends approximately 15 miles along the Taylor Highway in the vicinity of Mt. Fairplay. Discovery of radioactive rocks on Mt. Fairplay resulted in considerable claim staking several years ago. The writer obtained readings of 0.04 to $0.05 \mathrm{Mr} / \mathrm{Hr}$, or four to five times the usua? background, along the highway through the area.

Location 74 -- Tertiary shale, sandstone, and coal beds exposed along Chicken Creek at the town of Chicken and in a gravel pit near Chicken did not yield significant readings. The Silver Queen Lode, just below the highway about four miles north of Chicken and near Mile Post $7 T$ did not show measureable radioactivity. The prospect consists of a 30-foot tunnel following a gouge zone with showings of galena.

Location 87 -- Two feet of gouge in a fault zone in a conspjcuous outcrop of marble in a road cut at Mile Post 114 gave three times the background count, or between 0.03 and $0.04 \mathrm{Mr} / \mathrm{Hr}$. Tertiary sandstones and shales exposed in borrow pits along the Taylor Highway from a few miles south of Eagle to Eagle contain sandstone shales, and siltstones. The very fine-grained silty sandstones and siltstones were noticeably higher in radioactivity than the cleaner, coarser sandstones. Counts up to $0.03 \mathrm{Mr} / \mathrm{Hr}$ were obtained.

Location 88 - A foot traverse along American Creek from Eagle south for five miles was made to examine Tertiary sandstones and conglomerates exposed in bluffs along the creek. At three locations localized anomalies were encountered where faults cut these beds. The maximum readings were $0.03 \mathrm{Mr} / \mathrm{Hr}$. Mission Creek enters the Yukon just west of the town of Eagle near the base of Eagle Bluff. The prominent Eagle Bluff stands between Mission creek and the Yukon. In the 1940's several claims covering showings of gold, copper, nickel, and cobalt were staked along a fault zone on the Mission Creek side of Eagle Bluff. A foot traverse in this area did not produce any radioactive anomalies, but all seven claims were not examined in detail. No mining has been done on the claims.

Location 89 -- Frequent checks with counters along the Yukon River between Eagle and the Canadian border revealed no anomalies in the Paleozoic rocks exposed. The Nation River conglomerate exposed at points between two and eight mi les downstream from Eagle produced no anomalous readings. The Mississippian Calico Bluff formation exposed on Calico Bluff about eight miles downriver from Eagle has been reported to contain radioactive black shales. The writer measured readings up to $0.05 \mathrm{Mr} / \mathrm{Hr}$ in black shales near the base of the bluff. A climb from the river to the top of the bluff produced lesser readings. Tertiary beds exposed on the south side of the Yukon from two to seven miles west of the mouth of the Seventymile River produced only very low radioactivity. A maximum reading of $0.05 \mathrm{Mr} / \mathrm{Hr}$ was obtained from one narrow brecciated zone cutting the beds.

CANTWELL, MOUNT MCKINLEY PARK AREAS

AND LOCATIONS ADJACENT TO THE RICHARDSON AND DENALI HIGHWAYS

(Locations $66,67,68,69,71$ )

Location

The areas covered under this section include (1) Fafrbanks to Mt. Mckinley Park along the Alaska, Richardson, and Denali Highways, (2) coal and silver-antimony mines in the west 
fork of the Chulitna River district, (3) the Cantwe11-Mckinley Park road, and (4) the road inside the park. Nearby mines, prospects, and accessible outcrops were examined.

\section{Purpose}

The rocks of primary interest during this radioactive survey were the Tertiary coalbearing beds, the Cantwe 13 conglomerate, and the acidic intrusions in the region.

\section{Geology}

The areas lie in the east and central parts of the Alaska Range and the foothilis on the north and south flanks of the range. The rock units traversed include schist of Precambrian age and metamorphic, volcanic, and granitic rocks of Paleozoic and Mesozoic ages. Tertiary sediments are present in scattered areas at lower elevations. The Cantwell conglomerate of Cretaceous age forms a prominent thick deposit in the Cantwell-Mckinley Park area.

\section{Results}

A variety of rock types along the routes were checked for radioactivity. Coal mines in Tertiary beds and accessibie hard rock mines and prospects were examined. No strong radioactivity was detected, but the more interesting sites visited are described here.

Location 71 -- The Delta coal mine at the head of Ober Creek is eight and one half miles by gravel road southeast from the Richardson Highway in the Mt. Hayes $\mathrm{C}-4$ quadrangle. This is the site of an abandoned open-pit coal mining operation. The principal coal seam is about six feet thick. The exposure reveals about 30 feet of soft shales and sandstones containing some conglomerate beds of quartz and chert pebbles overlying the coal. No radioactive anomaljes were detected.

Location 70 -- The traverse along the Richardson and Denali Highways includes the three areas described here.

An abandoned stibnite mine is located about $1 / 4 \mathrm{mile}$ east of Richardson Highway and opposite the terminus of Black Rapids Glacier. An old tunnel on the east side of a small "hidden" lake is flooded and could not be entered. However, a gouge zone, a two-foot silicified mass with jasperoid and iron staining, and white quartz were present at the mine entrance. No significant radioactivity was noted.

The Rainbow Mountain area is on the east side of Richardson Highway in the Mt. Hayes B-4 quadrangle. This is a mineralized area which contains gold, silver, lead, and copper prospects. Brightly colored flow rocks and dikes, some containing a large amount of disseminated pyrite, are conspicuous in certain locations. No radioactivity was noted.

The Windy Creek-Valdez Creek district is north of the Denali Highway and east of Susitna River. A local prospector, "Tex" Greathouse, living near the Susitna Lodge, allowed the writer to examine a collection of ore samples and rocks from the general area, which is principaliy a copper district. None of the collection produced anomalous radioactivity. 
Location 66 -- Two areas are included under this location.

A crushed zone cutting the undifferentiated Paleozoic-Mesozoic shales exposed in a road cut 2.8 miles north of the junction near Cantwell produced an anomaly of three times background. Abundant iron oxide staining and pyrite were found uphill but no radioactivity. A 10-pound sample of the crushed fron-stained shale retained its radioactivity for several weeks. Later, a test showed none. This indicates the radioactive material was radon gas.

The abandoned Coal Creek coal mine is located between Sunmft and Broad Pass. A six-foot bed of low grade coal on the west side of Coa 1 Creek is exposed along a gully. No radioactivity in the coal, shales, or gravels was noted. At the old Broad Pass coal mine adjacent to the road at Broad Pass the results were also negative.

Location 67 -- The Dunkle coal mine is on Costello Creek, tributary of the West Fork Chulitna River, in the Healy B-6 quadrangle. The site of this former large mining operation is at an elevation of 2,800 feet on the southern slope of the Alaska Range. The Tertiary coals are similar to those at numerous areas along the flanks of the Alaska Range. The beds dip as much as $20^{\circ}$ and faulting is common. Both underground and surface mining has been done. No anomalies were found in Tertiary sediments. Flows and intrusive rocks adjacent to the south 1 imtt of the Tertiary beds and near the coal mine contain some scattered pyrite and arsenopyrite. A bluff across the creek behind the abandoned mining camp produced up to $27 / 2$ times the background count.

Location 68 -- The Silver King mine is an inactive silver-antimony prospect located on a low hill on the east side of Colorado Creek and about three miles south of the Dunkle coal mine. The location is about a mile north of that shown on the USGS Healy A-6 quadrangle map. Mineralization is associated with a quartz diorite stock which has intruded argilitite, limestone, and greenstone. Several trenches have exposed arsenopyrite, chalcopyrite, and stibnite. No radioactivity could be detected.

Location 69 -- This location includes traverses along the Nenana River between Cantwe]l and Mount McKinley Park Station and areas adjacent to the road through Mount Mckinley Park. Tertiary sediments, the Cantwe 11 conglomerate, lavas, and intrusive rocks were checked. No significant radioactivity was located.

\section{ALASKA PENINSULA AREAS}

Location

Three areas in the Alaska Peninsula region were visited; Port Moller, Popof and Unga Is lands, and Chignik.

\section{Purpose}

The presence of nonmarine sandstones and much volcanic material prompted the writer to examine these selected areas for possible radioactivity. It has of ten been postulated that the source of some uranium is volcanic ash and debris from which the uranium may have been leached and later concentrated in nearby normarine sandstones. 
Geology

Paleozoic rocks are not exposed in the central part of the Alaska Peninsula visited by the writer. Early Jurassic intrusives make up the backbone of the Alaska Peninsula. These granites and younger sediments were the source of a thick Upper Jurassic and Lower Cretaceous arkosic sequence. Both marine and nonmarine volcanic materials and sediments accumulated during Early Tertiary time. Volcanism and the emplacement of quartz diorite plutons became widespread. The present structures are post Miocene, and uplift is continuing.

\section{Results}

Locations

111 \& 112 - Foot traverses were made along the coast around Port Moller Bay and inland on the peninsula between Port Moller Bay and Herderdeen Bay and across Staniukovich Mountain. Sandstones, conglomerates, and volcanics of the Tertiary Bear Lake and Tolstoi formations and the Cretaceous sandstones, conglomerates, coal beds, and limestones of the Chignik and Herderdeen formations were examined. The maximum radioactivity encountered was in a small lens of coal in the Chignik formation on the west coast of Port Moller Bay. This gave $21 / 2$ times the normal background count. The Staniukavich sandstone near a mineral spring and cabin, locally known as Hot Spring, gave a slight increase in count.

Locations 108

109 \& 110 -- Radioactivity investigations were conducted in the vicinity of the old Apollo and Sitka mines on the southeast part of Unga Island. The two mines are situated within several hundred yards of each other. They were last worked in about 1912. Mineralization includes gold, pyrite, galena, sphalerite, chalcopyrite, and native copper. The gangue is quartz, calcite, and orthoclase. The ore is in reticulated zones cutting andesite and dacite. The zones strike $\mathrm{N} 20^{\circ} \mathrm{E}$ and are nearly vertical. No radioactivity was detected. Geochemical soil sampling by the writer failed to indicate extensions of the veins.

Traverses along the north and northwest coasts of Unga Island revealed Tertiary sandstones, shales, and coal beds and an abundance of petrified wood, but no abnormal radioactivity. The lavas along the west coast of Popof were examined with negative results.

Locations

106 \& 107 -- Coal has been mined at several points along the coast near Chignik, on Chignik Bay. Sediments examined in this area inclüde the Jurassic Naknek formation sandstones and the Cretaceous Chignik formation sandstones, conglomerates, and coal beds. No anomalous radioactivity was found.

One day was spent investigating an old copper prospect on Warner Bay (Prospect Bay), which is on the coast due south of Chignik. There are two short tunnels in the Tertiary quartz diorite bluff near the shoreline on the north side of Warner Bay. Pyrite, chalcopyrtte, galena, and molybdenite were seen on the surface in scattered pockets and on fracture surfaces. Only radioactivity normal for these rocks was encountered. 
Location 52 -- Two days were spent examining the large open pit coal mines at Jonesville and Eska, approximately 50 miles northeast of Anchorage. Only weak (not over twice background) radioactivity counts were noted.

\section{CONCLUSIONS}

In Alaska the largest numbers of radioactive anomalies have been found on the Seward Peninsula and in Southeastern Alaska. Numerous assays have shown sufficiently radioactive igneous rocks within the State to suggest that new comercial uranium deposits will be found. Large areas are still untested and relatively little work has been directed to the exploration for sedimentary-type deposits. The writer believes that the climate in Alaska and the disturbed positions of the younger sediments are factors which make it difficuit to detect ores of Tertiary age. Weathering processes and the widespread presence of tundra make diamond drilling and trenching more necessary in Alaskan prospecting than in more arid regions.

Large free-world reserves have been located in Precambrian conglomerates, and because there is evidence that more radioactive material was available during Precambrian time, it may be wise to search for those rocks and sediments derived from them.

Aerial radiometric surveys and helicopter support are desirable for uranium exploration in remote areas of Alaska. Geochemical and geobotanical prospecting methods may prove to be helpful where tundra and vegetation cover the bedrock, but more experimental work involving their application to uranium minerals is needed. The writer plans to sample in known mineralized areas during 1969 in order to test these procedures. 


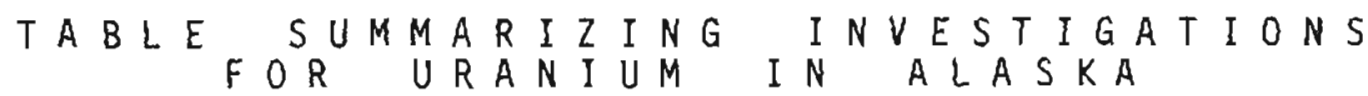

The symbols and abbreviations used in each of the seven columns, from left to right, are explained under the appropriate headings.

Location Numbers: Numbers listed in sequence in the table correspond with locations on the map.

Locality Name: Names of localities generally are those used in the U. S. Geological Survey reports. The locations can be found by use of quadrangle maps and reports listed under references.

Quadrangle: Quadrangle names are those of the U. S. Geological Survey.

References to Radioactivity Investigations:

Examples of abbreviations are as follows:

8 1154: U. S. Geological Survey Bulletin 1154.

PP 302-A: U. S. Geological Survey Professional Paper 302-A.

C 196: U. S. Geological Survey Circular 196.

TEM: $\quad$ U: S. Geological Survey Trace Elements Memorandum. These are unpublished reports of 1 imited distribution concerning work done on behalf of the U. S. Atomic Energy Commission. Same have been republished as bulletins or circulars.

TEI: $\quad$ Trace ETements Investigation reports. These are unpublished reports of limited distribution prepared by the U. S. Geological Survey. Some have been republished as bulletins or circulars.

Map I-530: U. S. Geological Survey Miscellaneous Geologic Investigations Map I -530 .

IR: Alaska Territorial Department of Mines unpublished Itinerary Report. These are on file at the Alaska State Division of Mines and Geology office at college.

MI: $\quad$ Alaska Territorial Department of Mines unpublished Mineral Investigation. These are on file at the State Division of Mines and Geology office at College.

MR: $\quad$ Alaska Territorial Department of Mines unpublished Miscellaneous Report. These are on file at the State Division of Mines and Geology office at College.

PE: Alaska Territorial Department of Mines unpublished Property Examination. These are on file at the State Division of Mines and Geology office at college.

Country rock: Principal bedrock in the general area. 
Mineralization: Includes known minerals and ores of general area. Minerals and elements listed may or may not be of economic importance. Chemical symbols for elements are as follows:

$\begin{array}{llr}\text { Ag silver } & \text { Cr chromium } & \text { Pt platinum } \\ \text { As arsenic } & \text { Cu copper } & \text { Sb antimony } \\ \text { Au gold } & \text { Fe iron } & \text { Sn tin } \\ \text { Ba barium } & \text { Hg mercury } & \text { Th thorium } \\ \text { Be beryllium } & \text { Mo molybdenum } & \text { U uranium } \\ \text { Bi bismuth } & \text { Mn manganese } & \text { W tungsten } \\ \text { Co cobalt } & \text { Ni nickel } & \text { Zn zinc } \\ \text { Cd cadmium } & \text { Pb lead } & \end{array}$

Radioactivity Measurements: Geiger counters and scintillometers are frequently used to assay radioactive minerals. The counters used in early investigations could not distinguish between radiation from uranium, thorium, or potassium, so the assays are reported as "equivalent uranium" (eU), which is a measure of the total radioactivity in terms of the amount of uranium which would be required to yield the count obtained. Assays reporting el generally include radioactivity due, in part, or entirely to thorium and potassium, particularly if no minerals were identified. Assays by other methods may be reported as percentages of $\mathrm{U}_{3} \mathrm{O}_{8}$, the form in which ore assays are generally given. The compound $U_{3} O_{8}$ contains approximately 85 percent uranium. Chenical assays of course, are the most accurate method of evaluation, and show uranium content in percent or parts per million.

A large portion of the samples collected in Alaska by the Geological Survey were stream sands and gravels. These were washed to concentrate the heavy fractions, which were then assayed. It was believed that this method would locate primary uranium minerals if present in the drainage area. It is difficult, however, to evaluate these assays and relate them to bedrock values unless concentration factors are known. The concentration ratios may be several hundred or even several thousand to one. Unconcentrated samples are the most meaningfu1. Counters are usually designed with meters that read in milliroentgens per hour $(\mathrm{Mr} / \mathrm{Hr}$ ) and for general reconnaissance work this reading, is often all that is reported. This gives a relative value when compared to the background reading. 


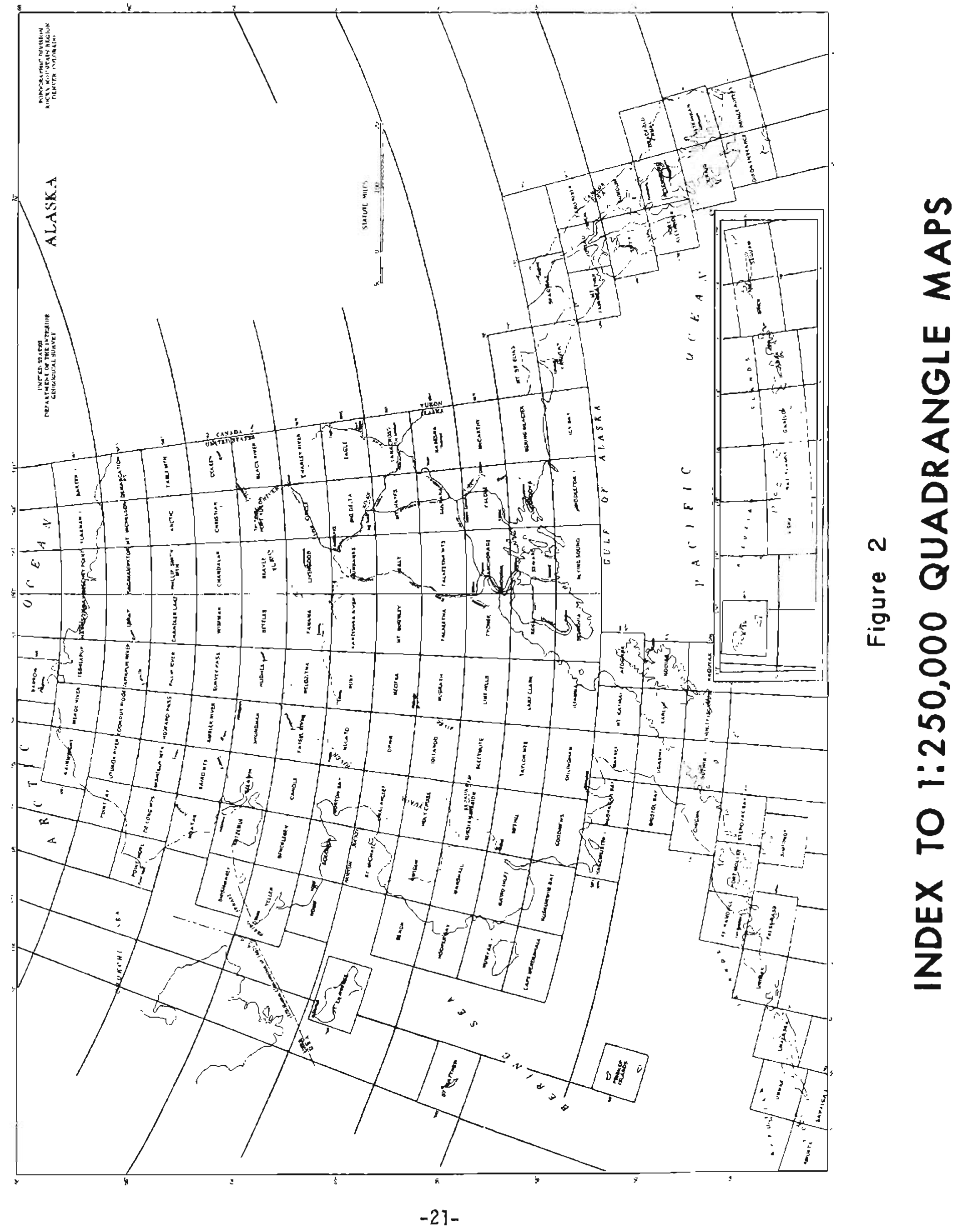




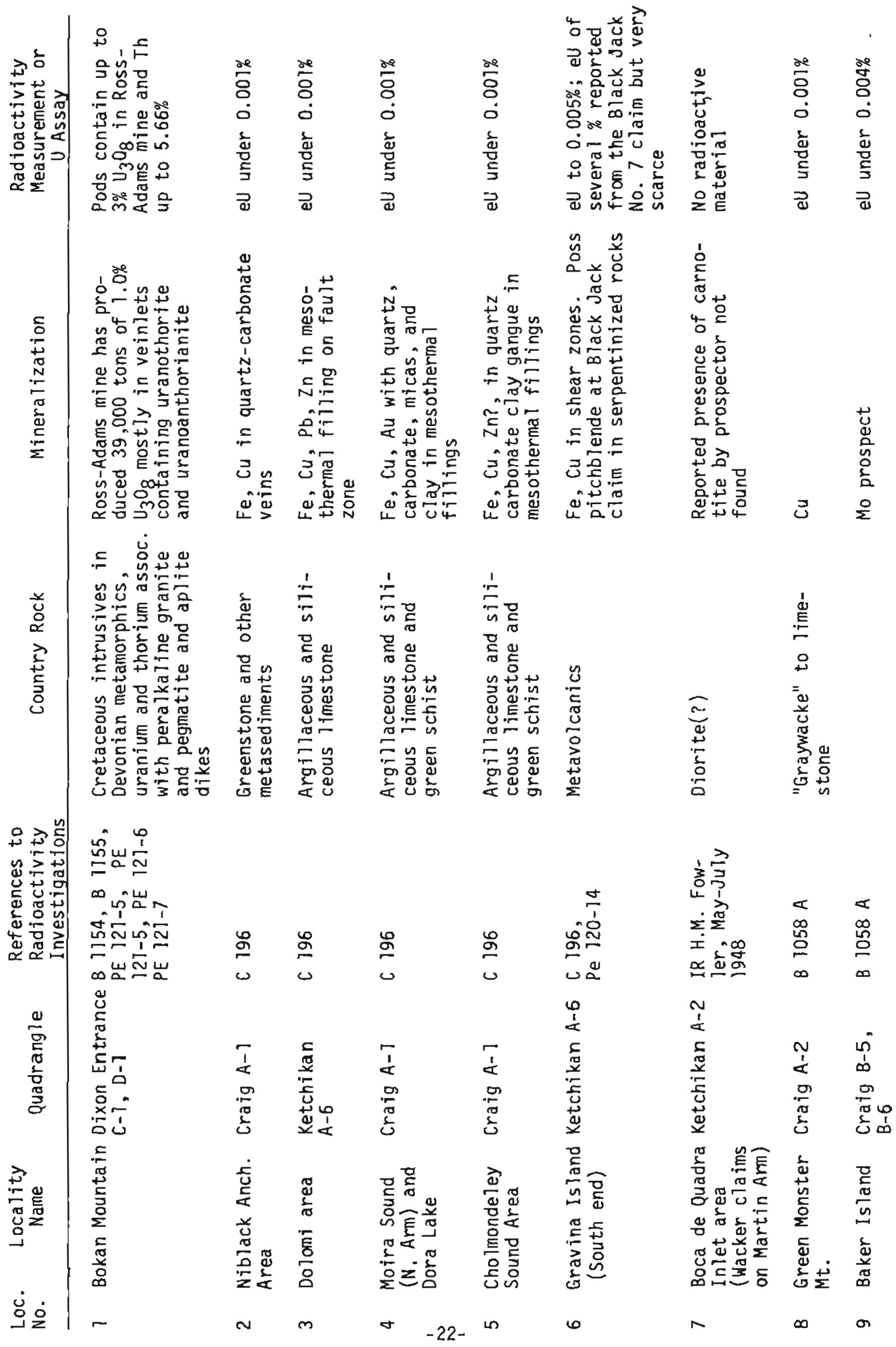


10 -Ketchikan vicinity

11 Mahoney Mine George In let

12 Kassan Penn. (?)

13 Kassan Penn. Crajg B-7,

14 Helm Bay

15 Union Bay

$\stackrel{1}{\sim}$

16 Hyder Mining District

17 Egg Harbor, Coronation Is land

18 KosciuskoShaken and Shipley Bays $\mathrm{C}-1, \mathrm{C}-2$

Ketchikan B-5 B 1024 B

Ketchikan B-5 PE 120-9

Craig B-1 (?) C 202, TEM 235

Crajg $\mathrm{C}-\mathrm{l}$

Craig $C-1$

C 196

Ketchikan D-1 B 1024 B, TEM Brandfield Cana 1 A-1 $235,81058 \mathrm{~A}$, PE 120-1], IR Fowler, 1949
Ketchikan C-6 C 196
Metasediments and diorite

Sandstone, slate cut by guartz diorite

Jurassic volcanics

Graywacke, slate, 1 jmestone and diorjte stocks

Green schist and greenstone

Metasediments and mafic to ultramafic rocks

Granodiorite, quartz monzonite, greenstone and metasedjments
$\mathrm{Au}, \mathrm{Fe}, \mathrm{Cu}, \mathrm{As}, \mathrm{Bt}, \mathrm{Sb}$, in quartz fissure veins

$\mathrm{Au}, \mathrm{Ag}, \mathrm{Cu}, \mathrm{Pb}, \mathrm{Zn}, \mathrm{Cd}(\mathrm{Tr})$ in a vein with quartz and carbonates

Cu-Fe deposits and $\mathrm{Pb}-\mathrm{Ag}$ veins

$\mathrm{Fe}, \mathrm{Cl}, \mathrm{Mo}$ and contact metamorphic minerals at diorite-sediment contacts

$\mathrm{Fe}, \mathrm{Cu}$, Au in quartz, sercite, talc and graphitic material in fracture zones

No ore found, but a sample of tyuyamunite in coaly materia] was reported to be from Union Bay

Mostly near contact of the Texas Creek granodiorite and the Hazelton group of metamorphic rocks. $\mathrm{Ag}, \mathrm{Au}$, $\mathrm{Pb}, \mathrm{Zn}$, Mo in fissure veins and replacements. Smal1 amount of $U$ associated with hematite and limonite and with the sulfides

$\mathrm{Pb}$ prospect

Crajg D-7, B 1058 A D-8

Craig D-5

B $7058 \mathrm{~A}$
Graywacke to limestone
Calcite veins; one small galena vein]et
eU under $0.001 \%$

Not tested, but favorable minera] ogy

el in $\mathrm{sp1}=0.1 \%$ in allanite

(TEM 235. p. 63)

eU under $0.001 \%$

ef under $0.001 \%$

Tyuyamunite over $1 \%$ (?) 1951 investigat ion, eU under 0.001

el of $0.049 \%$ from Mountain View property and many lesse shows in area. Unverified report of one Mounta in View sample assayed $0.7 \%$ elf

eU under $0.004 \%$

ev under $0.001 \%$ 

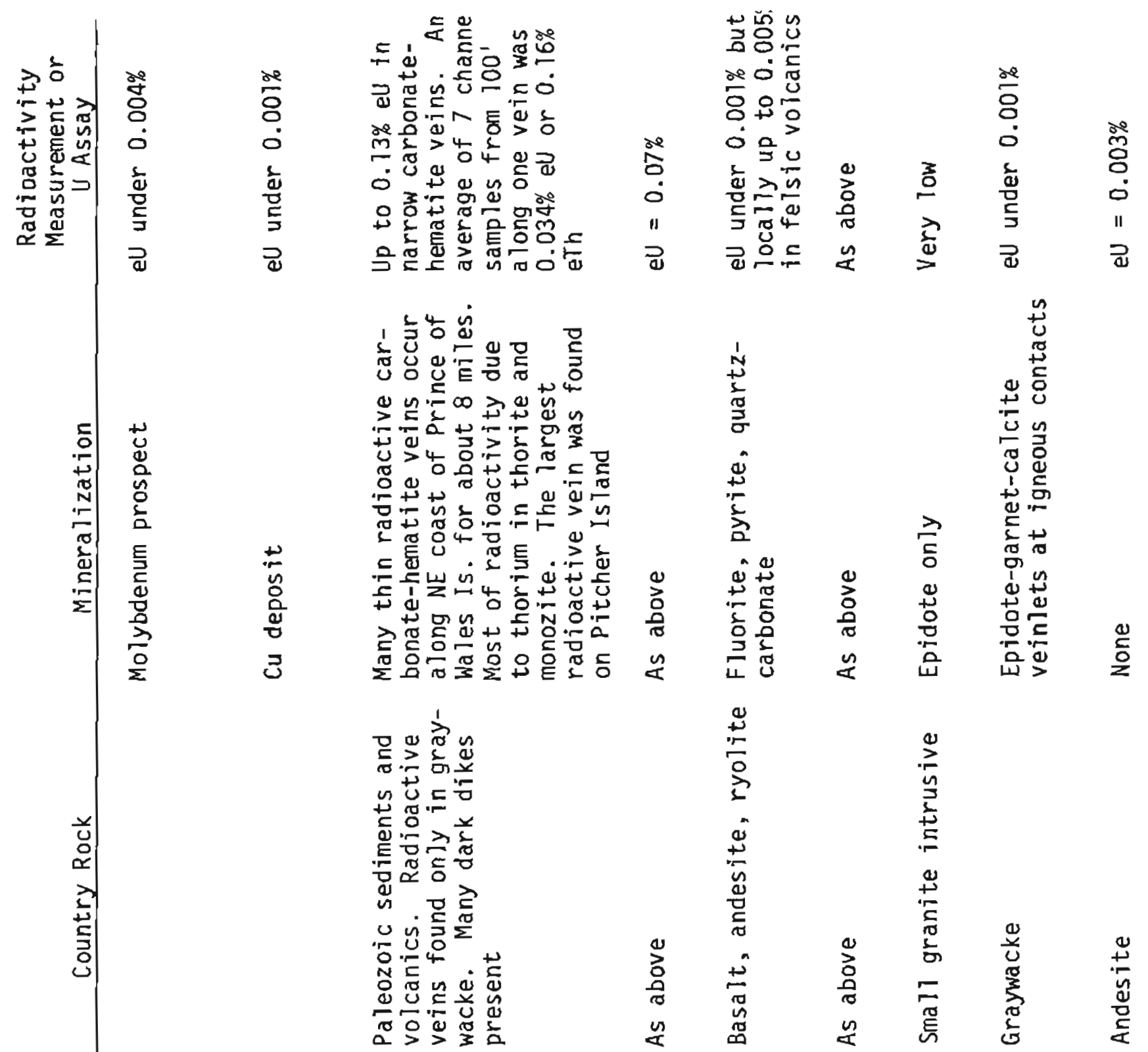

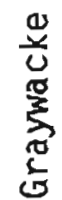

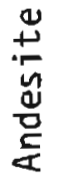
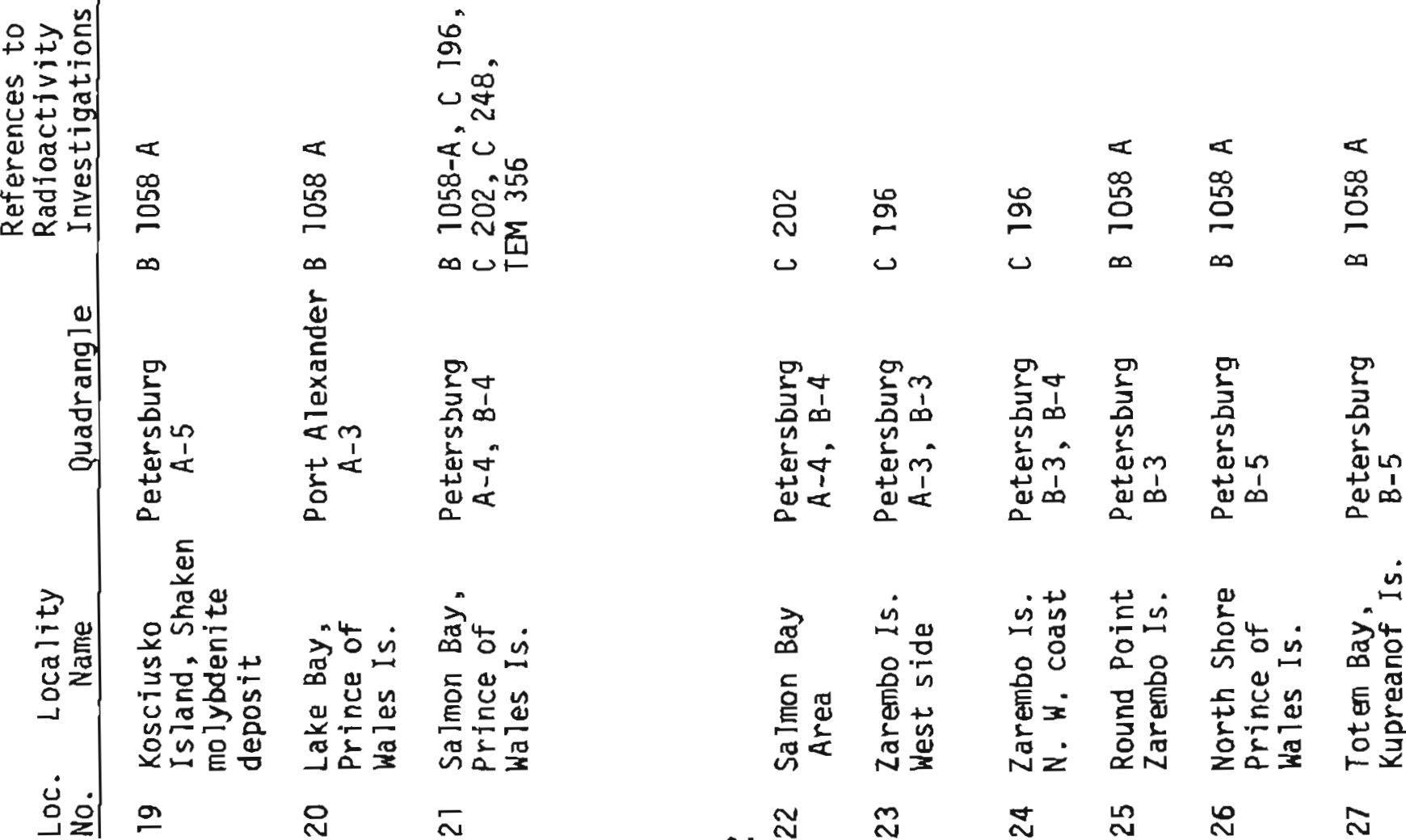

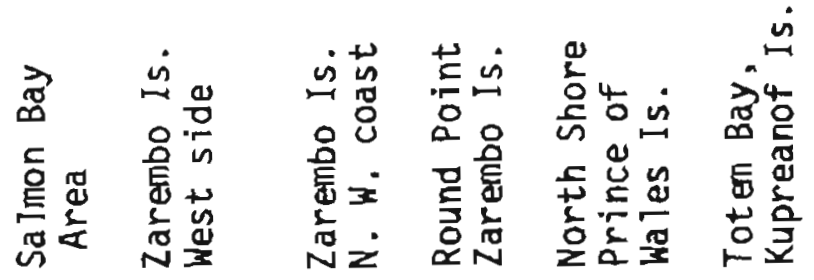

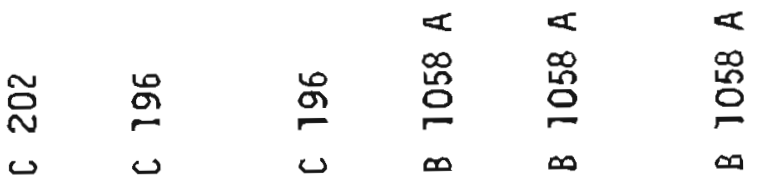

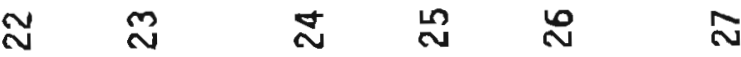




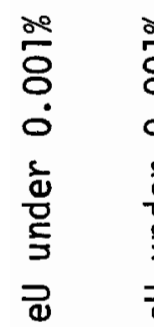

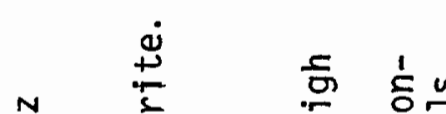

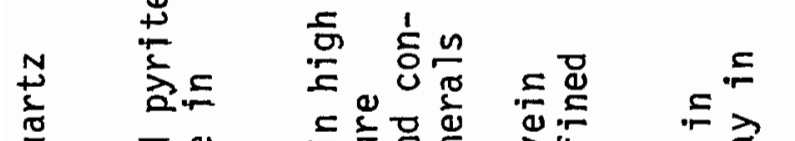

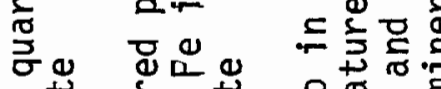

E)

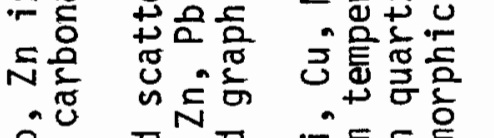

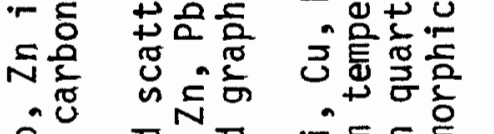

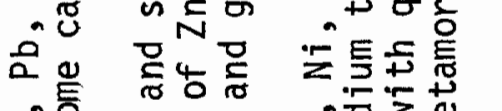

J每

उon

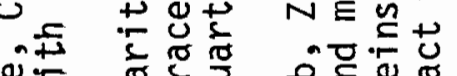

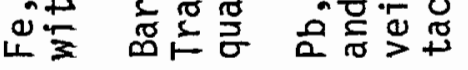

$>\frac{1}{4}$

$\therefore \frac{1}{n+1}$

舟要

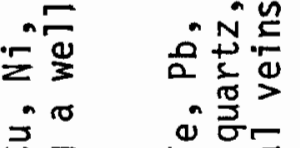

Uु

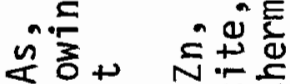

4

थक्ष

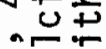

ต

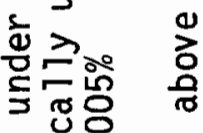

道

$\overrightarrow{0}$

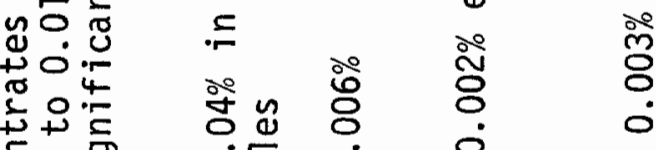

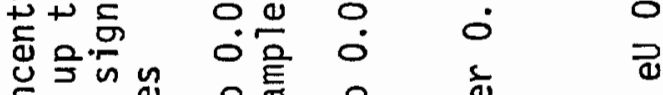

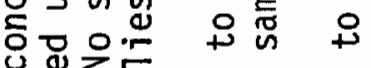

음. 응

윽 웜 윽

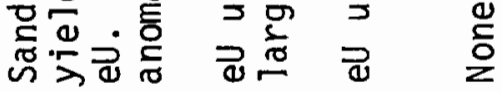

㧫
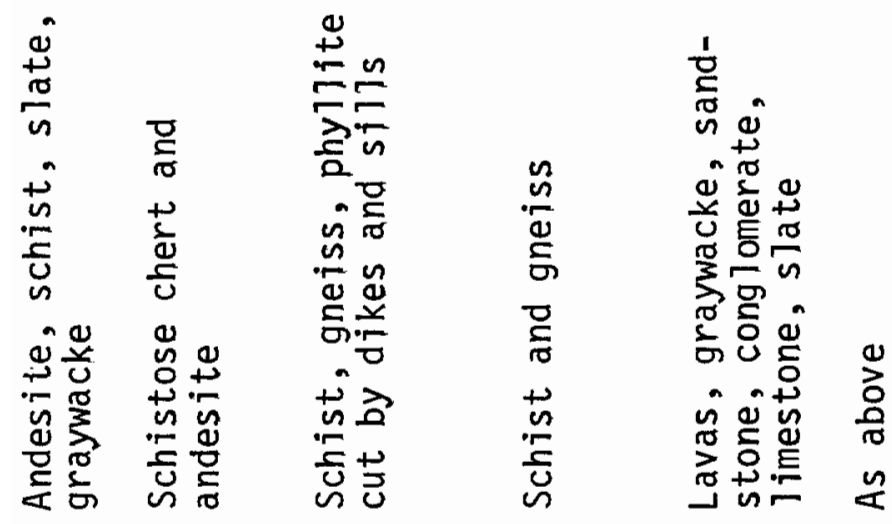

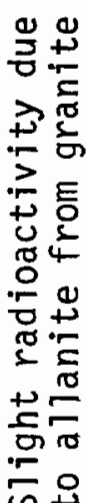

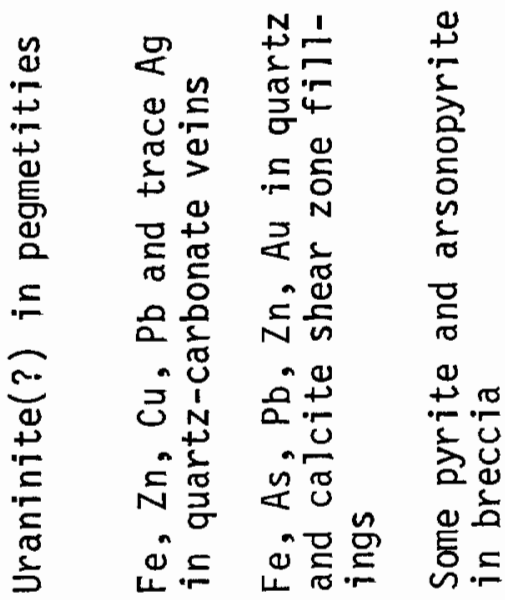

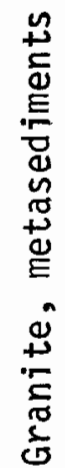

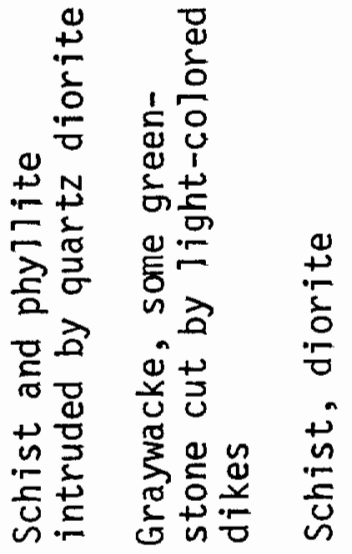

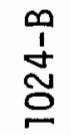

잉

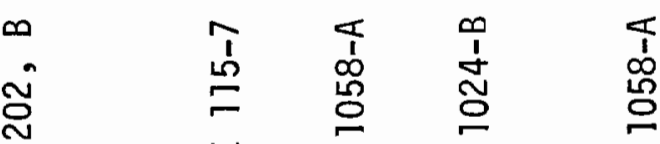

u v $u$ u $u$ v

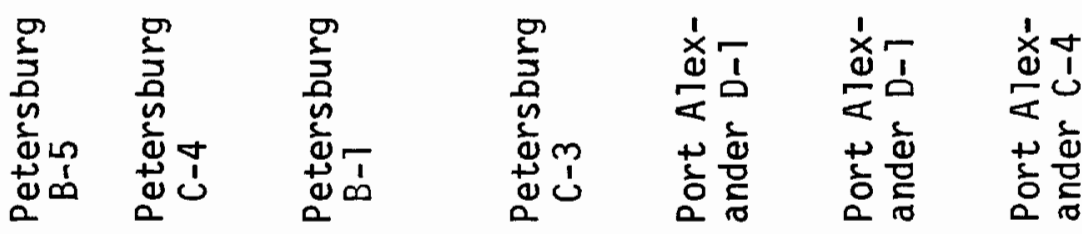

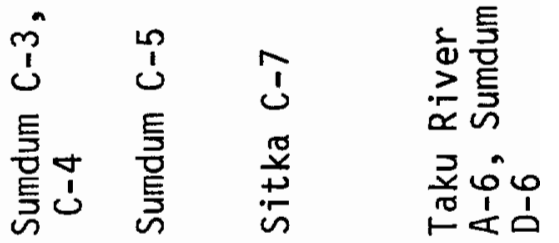

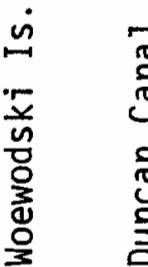

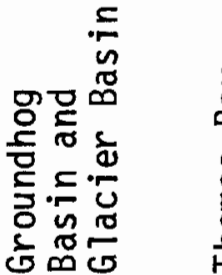

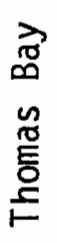

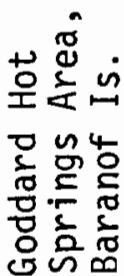

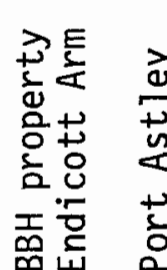

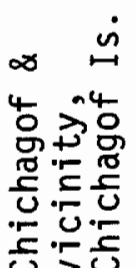

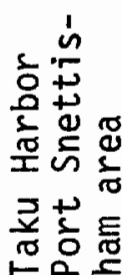

ฉ

요

$\bar{m}$

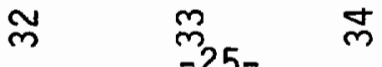

m

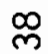


39 Juneau \& Juneau B-1, B 7024-B vicinity B-2

40 Funter Bay Juneau A-3 B T024-B Admiralty Is.

41 William Henry Juneau C-4 B TI55 Bày area, Lucky Six claims Monument

43 Yakataga Beach

\section{Bering}

Glacier A-4

C $184, C 202$

44 Nizina Dist. McCarthy B-5 C 184 (Kennecott McCarthy Area)
Schist, s]ates, greenstone intruded by aplite dikes, gabbro and basalt

Greenstone, schist, gneiss $\mathrm{Ni}, \mathrm{Cu}, \mathrm{Au}, \mathrm{Fe}, \mathrm{Pb}, \mathrm{Zn}, \mathrm{As}$ marble, and a variety of in quartz veins or sills dikes and sills

Meta jgneous small red patches in bed-

Quartz-diorite, a]tered rhyolite, andesite dikes

Metamorphosed Paleozoic $\mathrm{Cu}, \mathrm{Au}, \mathrm{Ag}, \mathrm{Ti}, \mathrm{Fe}, \mathrm{Mo}, \mathrm{Ni}$ and Mesoic sediments; Mesozoic and Cenozoic intrusives

Tertiary (most]y marine) sandstone, arkose, graywacke, shale, limestone and conglomerate underlie area adjacent to Yakataga Beach

Permian, Triassic and Cre- Bonanza copper produced taceous greenstone, lavas, from the Kennecott mines. 1 imestone, shale and sand-Principal ore is $\mathrm{Cu}-\mathrm{Ag}$ and stone intruded by quartz placer Au. Some Mo, Pb, diorjte djkes and sills $\mathrm{Hg}$

As above

Placer Au
$\mathrm{Fe}, \mathrm{Zn}, \mathrm{Ni}_{i}, \mathrm{~Pb}, \mathrm{Zn}, \mathrm{Au}, \mathrm{Mo}$, As, in quartz, mica, car-

bonate gangue

Traces of thorianite in rock

Specks of purple fluorite in iron-stained rhyolite; no sulfides or gangue

$\mathrm{eU}=0.001 \%$

eul $=0.007 \%$

el up to $0.2 \%$

(thorium?)

el up to $0.22 \%$, one hand-picked sample $=1.2 \%$ el

Maximum of $0.003 \%$ $\mathrm{U}_{3} \mathrm{O}_{8}$ from Sandy Cove

Beach sands examined. Zircon group of minerals found to be radioactive. Gold has been placered from beach sands
9 beach placer concentrated samples averaged $0.044 \%$ el, one of these had $0.320 \%$ el

Panned concentrates el under $0.002 \%$. $\mathrm{Nc}$ underground examinations reported

Placer concentrate $=$ $0.004 \%$ el probably due to zircon and sphene 
46

Moose Pass + Seward $C-6$,

C 196 Hope area $\mathrm{C}-7, \mathrm{D}-6, \mathrm{D}-7$

47 Girdwood

Anchorage

C 196

Area

$A-6, A-7$

48 Areas adjacent Valdez A-5,

to Richardson A-6, A-7, B-4

Highway - Val- C-4

dez north to

Willow Lake

49 Chitina Area Valdez C-2 C 184

50 Locations Ad- Anchorage

jacent to

Glena llen

Highway, Anch.

is to Tahneta

$\checkmark$ Pass

5T Wi llow Creek District

Anchorage C-6 C 184 C-7

Anchorage D-5 C 184 and this D-6

report

Eska coa

District

53 Albert Creek Talkeetna A-1 C 184

and Crooked

Creek Area

54 Iron Creek

Area, Ta]-

Talkeetna B-5 C 196

keetna Dist.
Mespzoic metasediments cut by acid dikes

Mesozoic argillite and graywacke with quartz diorite dikes and silis

Predominantly Cretaceous sediments, graywacke; Carboniferous metasediments

and volcanics

Carboniferous metasediments

Mesozoic metasediments and Tertiary sha]e, sandstone and coa?

Granjte, porphery and Birch Creek schist; various dikes

Rich Au veins and placers. Gold lodes in both quartz diorite and schist

Tertiary sandstone, shale coa] and coal

Jurassic sediments and volcanics

Andesjte flows, Mesozolc $\mathrm{Cu}$, hematite in replacesediments and granodiorite ments in andesite el $=0.002 \%$ or less

el under $0.002 \%$

Panned concentrates eU $=0.005 \%$ or less

$\mathrm{eU}=0.000 \%$

$\mathrm{eU}=0.002 \%$

Average of 11 sample of pegmatites = $0.004 \%$ el'; heavy fractions average $0.032 \%$ ell

Sight radioactivity count up to three times background in shales

$\mathrm{eU}=0.000 \%$

$\mathrm{eU}=0.002 \%$ or less 
63 Alaska Highway belt, upper Tanana valley

64 Tanana River Traverse

\section{Tanacross}

C 331, this report

Big Delta, Mt. B 1155

Hayes, Tanacross

65 Maclaren River Mt. Hayes B-6 B 1155

66 Highway Area Healy B-4, This report Cantwe] 1 to Mckinley Park

67 Dunkle Coal Healy B-6 Mine, Costello Creek

1
0

68 Silver King Mine, W. Fork

Chutitna River

Area

69 Mckinley Park Road, Park Entrance to wonder Lake

Hea Ty A-6

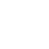

Healy $\mathrm{C}-5$ $\mathrm{C}-6, \mathrm{Mt}$. McKinley B-1, B-2

70 Richardson Highway, Deita Jct. -

Mt. Hayes $A-3$ This report $A-4, B-4, C-4$ and $C 33]$

Paxon

71 Delta Coal Mine, Ober Creek report

This report

This report D -4

Mt. Hayes $\mathrm{C}-4$ This report
Mostly Mesozoic (?) gran- Slight radioactivity due jtic intrusives; Paleozoic to accessory minerals zir schists and gneiss

con and allanite in granite

Granite, gneiss, schist

Triassic diabasic lava

$\mathrm{Cu}$ in quartz veins

Sandstone and conglomerate of rantwell formation sma 1] granitic intrusive. Tertiary sands near Yanert

B 1155 and this

Eocene sandstone, shale and coal beds

Coal has been mined
Cherty limestone, argil- Sb, Fe lite, nearby diorite

Mostly Triassic and Cre- Not on road taceous sediments and lavas

Pre-Cambrfan or Paleozolc Placer Au, Sb schist, Mesozoic sedjments tuffs, dikes, and granitic intrusives

Tertiary sand, grave], clay, coal
$\mathrm{eU}=0.004 \%$ or less, from granite out crops and stream concentrates

Maximum el $=0.006 \%$ in granite at

Cathedral Bluffs

$\mathrm{eU}=0.003 \% \operatorname{maximum}$

Maximum reading was 4 times background in crushed zone in shale bank $2.8 \mathrm{mi}$. N Denali Highway

Slight radjoactive coa] reported but no anomalies found by later investigations

No a noma 1 ies

No anomalies

No significant anomalies. Panned concentrates maximur $=0.01\}$ eU from ober Creek

No anomalies 


$\begin{array}{lccccc}\text { Loc. } & \text { Locality } \\ \text { No. } & \text { Name } & \text { Quadrangle } & \begin{array}{l}\text { References to } \\ \text { Radioactivity } \\ \text { Investigations }\end{array} & \text { Country Rock } & \text { Mineral } \\ 72 \text { Ober creek } & \begin{array}{c}\text { Mt. Hayes } \\ \text { C-4 }\end{array} & \text { C } 202 & \text { Schist and gneiss } & \text { Placer Au }\end{array}$

Radjoactivity

Measurement or U Assay

73 Taylor Hwy.

Tanacross B-3, B 1155; this $B-4, C-3, D-3$; report Eagle $A-1, A-2$ $\mathrm{B}-1, \mathrm{C}-\mathrm{l}$

74 Fortymile cluding Chicken

$\stackrel{1}{0}$

75 Richardson Hwy Area, Fbks. to Richardson

76 Bonnifield Dist., Grubstake Creek

77 Liberty Bel] Fairbanks A-4 C 196 Mine \& Calif. Creek prospect Nenana Dist.
Fairbanks $\mathrm{C}-1, \mathrm{C} 202, \mathrm{C} 331$ D-1, D-2; Big this report Delta B-5, B-6

Fairbanks A-3 MR $195-23$
Ryolite, granite, schist; Placer Au; minor Sn, W, Sb, Tertiary sandstone, shale $\mathrm{Hg}$ near Eagle

C 202, C 335 , c 348 , this report

Pre-Cambrian and Paleozoic Primarily placer Au; slight metamorphics, Tertiary volcanics, small granitic radioactive anonalies due to accessory minerals in intrusions granite. Fluorite prospect

Birch Creek schist, Meso- Au in quartz veins zoic (?) granjte

Tertiary sandstone, shales, gravels; nearby

Totatianika schist

Birch Creek schist, Totatlanika schist

\section{Placer Au}

$\mathrm{Fe}, \mathrm{Cu}, \mathrm{Au}, \mathrm{Sb}, \mathrm{Bj}, \mathrm{Ag}, \mathrm{As}$, $\mathrm{Pb}$ in quartz
Panned concentrates average $0.006 \%$ et and to $0.011 \% \mathrm{eu}$, due to monozite?

Maximum ef $=0.015 \%$ in granite and

aplite near Mt. Fai play. Other dikes and granites up to $0.006 \%$ eU

Maximum el $=0.005 \%$ in felsic igneous rocks and clay.

Traces of uranothor ianite at Atwater Bar, near Chicken, and placer concentrates elf up to $0.041 \%$

Maximum eJ $=0.006 \%$ in granitic rock. Anomally in schist near $M P 329=$ five times background count

Radjoactive, black sands reported - no data

$\mathrm{eU}=0.002 \%$ or Tess 
78 Healy Coal Healy D-4 This report District

79 Nenana Hwy, Fajrbanks C-3, This report Fbks to Nenana $\mathrm{C}-4, \mathrm{C}-5, \mathrm{D}-2$

80 Ester Dome Fajrbanks D-3 C 331 Area, Fbks. District

81 Lindgren-Fultz Livengood A-2 B 1155 ( $p$ 41) prospect, Fbks Fairbanks D-2 C 196 (Table 2) Dist; between

Fox and Flume

Creeks

\begin{tabular}{|c|c|c|}
\hline$\stackrel{\omega}{\omega}^{82}$ & $\begin{array}{l}\text { Pedro Dome- } \\
\text { Gilmore Dome } \\
\text { areas, Fbks. } \\
\text { District }\end{array}$ & $\begin{array}{l}\text { Fairbanks D-1, C 33T, C } 335 \\
\text { Livengood A-1 }\end{array}$ \\
\hline 83 & $\begin{array}{l}\text { Tolovana and } \\
\text { Cleary Hill } \\
\text { Mines, Fbks. } \\
\text { Oistrict }\end{array}$ & Livengood A-1 C 335 \\
\hline
\end{tabular}

84 Steese Hwy; Livengood A-6 C 331 Bell Creek to Circle B-4, North Fork B-5

85 Copper Creek Eagle D-5 Lode prospect, Eagle District

irch Creek schist, Mesozoic granite and quartz diorite

Birch Creek schist

Birch Creek schist; smal1 Placer Au granitic intrusives nearby

Birch Creek schjst with Au quartz Todes, minor As, minor granjtic jntrusions $\mathrm{Sb}, \mathrm{Fe}$

Weathered granite; Birch Creek schist

Mesozoic quartz

Birch Creek schist and granite
C 335 Fortymile Dist. hematite veins

\section{Placer Au}

$\mathrm{Pb}, \mathrm{Ag}$ with $\mathrm{Fe}$, quartz and carbonates in veins

$A u, B f, W$ Lodes and placer Au

Au, Sb, As, in faulted quartz veins

No significant anoma]les. Maximum radioactivity was three times the background

No significant anoma lies

Maximum eU $=0.007 \%$ from stream concentrates

eU under $0.01 \%$ but weathered pockets up to $0.025 \%$ eU

Panned concentirates to $0.066 \%$ el. Dutcrop samples = $0.007 \%$ elJ

$\mathrm{eU}=0.003 \%$

elJ $0.007 \%$ to $0.005 \%$ from outcrops: one concentrate $=$ $0.017 \%$ eu

One sample had $0.032 \%$ el. Others $=0.006 \%$ or less $\mathrm{Ag}, W ;$ in lime silicate rock small amount of uranium in copper minera is

$\mathrm{Pb}$, Sb (?), quartz and hematite veins

elt $=0.003 \%$ or less 


\begin{tabular}{|c|c|c|c|c|c|c|}
\hline $\begin{array}{l}\text { Loc. } \\
\text { No. }\end{array}$ & $\begin{array}{l}\text { Loca } 1 \text { ity } \\
\text { Name }\end{array}$ & Quadrangle & $\begin{array}{l}\text { References to } \\
\text { Radioactivity } \\
\text { Investigations }\end{array}$ & Country Rock & Mineralization & $\begin{array}{c}\text { Radioactivity } \\
\text { Measurement or } \\
\text { U Assay }\end{array}$ \\
\hline 87 & $\begin{array}{l}\text { Taylor Hiwy, } \\
\text { Boundry to } \\
\text { Eagle }\end{array}$ & $\begin{array}{l}\text { Eagle } A-1, A-2 \\
B-1, C-1, D-1\end{array}$ & $\begin{array}{l}\text { This report, } \\
81155\end{array}$ & $\begin{array}{l}\text { Birch Creek schjst, Meso- } \\
\text { zoic granite and quartz } \\
\text { diorite, Tertiary lavas, } \\
\text { sandstones and shales, } \\
\text { sone argillite and green- } \\
\text { stone }\end{array}$ & $\begin{array}{l}\text { Primarily placer Au; minor } \\
\text { placer Sn, } \mathrm{W}, \mathrm{Hg} ; \mathrm{Pb}-\mathrm{Ag} \\
\text { lode prospect }\end{array}$ & $\begin{array}{l}\text { High background } \\
\text { around Mt. Fairplay } \\
\text { up to } 4 \text { times norma }] \\
\text { Some Tertiary sands } \\
\text { had } 3 \text { times back- } \\
\text { ground }\end{array}$ \\
\hline 88 & $\begin{array}{l}\text { Mission Creek } \\
\text { area, Eagle } \\
\text { District }\end{array}$ & Eagle $0-1$ & $\begin{array}{l}\text { C } 202, \text { C } 316, \\
\text { this report }\end{array}$ & Granite & $\begin{array}{l}\text { Co, Au, Ni lode prospect } \\
\text { nearby }\end{array}$ & $\begin{array}{l}\text { Average el for } \\
\text { granitic rock }= \\
0.004 \% \text {, maximum } \\
0.006 \% \text {. Concentrates } \\
\text { to } 0.1 \% \text { el }\end{array}$ \\
\hline 89 & $\begin{array}{l}\text { Yukon River, } \\
\text { Canadian } \\
\text { Border to } \\
\text { Nation }\end{array}$ & $\begin{array}{l}\text { Eagle } D-1 ; \\
\text { Chariey River } \\
A-1, A-2\end{array}$ & $\begin{array}{l}\text { c } 316 \text {; this } \\
\text { report }\end{array}$ & $\begin{array}{l}\text { Devonian and Carboniferous } \\
\text { sediments; Permian Time- } \\
\text { stone; Tertjary sandstone, } \\
\text { shale and conglomerate; } \\
\text { greenstone, granite }\end{array}$ & $\begin{array}{l}\text { Placer } \mathrm{Au} ; \mathrm{Au}, \mathrm{Cu}, \mathrm{Co} \text { lode } \\
\text { prospect; hematite in the } \\
\text { Tindir group }\end{array}$ & $\begin{array}{l}\text { Maximum eU }=0.007 \% \\
\text { in Mississippian } \\
\text { b]ack shale and } \\
0.005 \% \text { in Mesozoic } \\
\text { granite }\end{array}$ \\
\hline 90 & $\begin{array}{l}\text { Slate Creek } \\
\text { Area (Ben } \\
\text { Creek area), } \\
\text { Fortymile } \\
\text { Dist. }\end{array}$ & Eagle B-4 & C 202, C 335 & $\begin{array}{l}\text { Ordovician sediments, } \\
\text { Mesozoic granite, } \\
\text { rhyolite }\end{array}$ & Placer Au; traces of $\mathrm{Pb}, \mathrm{Cu}$ & $\begin{array}{l}\text { el up to } 0.005 \% \text { in } \\
\text { rhyolite. Placer } \\
\text { concentrates = up to } \\
0.096 \% \text { el (as } \\
\text { gummite) }\end{array}$ \\
\hline 91 & $\begin{array}{l}\text { Coal Creek, } \\
\text { Charley River } \\
\text { Area }\end{array}$ & $\begin{array}{l}\text { Charley River } \\
A-5 \text { or } B-5\end{array}$ & C 202 & Granite (?) & Placer Au & $\begin{array}{l}\text { Placer concentrates } \\
\text { eu up to } 0.009 \% \\
\text { (in monozite sand) }\end{array}$ \\
\hline 92 & $\begin{array}{l}\text { Nome Creek \& } \\
\text { Hope Creek } \\
\text { Areas, fbks. } \\
\text { District }\end{array}$ & $\underset{B-6}{\text { Circle } B-5}$ & C 202, C 348 & $\begin{array}{l}\text { Birch Creek schist, gran- } \\
\text { itic intrusives }\end{array}$ & $\begin{array}{l}\text { Quartz-pyrite-fluorite veins } \\
\text { near schist-granite boundry. } \\
\text { Radioactive minerals assoc- } \\
\text { iated with granite not iden- } \\
\text { tified in most samples }\end{array}$ & $\begin{array}{l}\text { Placer concentrates } \\
=0.012 \% \text { el (Mon- } \\
\text { ozite) from Nome } \\
\text { Creek; one sample } \\
\text { granite talus = } \\
0.055 \% \text { el from Hope } \\
\text { Creek area. Others } \\
=0.004 \% \text { el or less }\end{array}$ \\
\hline
\end{tabular}


93 Good Luck $\mathrm{Cr}$; Livengood $\mathrm{C}-3 \quad \mathrm{C} 335, \mathrm{C} 331$ (Lucky Creek)

Livengood

District

94 Livengood Dist Livengood B-3 C 331

(See also Map $\mathrm{C}-3$

No. 93)

95 Bedrock Creek circle $\mathrm{C}-3 \quad 81155$ near Miller

House, Steese

Highway

96 Milier House-

Circle Hot

Circle $\mathrm{B}-2$,

$\mathrm{B}-3, \mathrm{C}-3$

C 202, C 335 ,

C 348,87155

Springs Area

97 Connell Pros- Charley River PE 57-4 pect, $28 \mathrm{Mile} \mathrm{C}-6$

Yukon River

98 Yukon River Fort Yukon and B 7155

Traverse, Fort Beavers

Yukon to ste-

vens Village

99 0'Keefe Placer Chandalar

B 1155

CTaim, chand-

a lar Dist.

(20 $\mathrm{mi} \mathrm{SW}$ of

Chandalar Lake)

100 Chandalar Chandalar 5- C 195, C 202, Dist. Big $\mathrm{Cr}$. To miles North $\subset 348$ and Lake $\mathrm{Cr}$. and East of

Areas Chandalar Lake
Chiefly Mississippian chert and silicified

limes tone

Paleozoic basic Tavas and metasediments; Tertiary acidic intrusives

Birch Creek schist; Mesozojc granite upstream

Birch Creek schist, Mesozoic granitic intrusive

Shale, sandstone

Few bedrock exposures

Early Pa]eozojc schist, gneiss, granite

Precambrian to Cretaceous sediments, Paleozoic and Mesozoic igneous rocks
Quartz-pyrite veins

Placer Au; Radioactive elixenite-polycrase series detected in concentrates

Primarily placer Au; rinor $\mathrm{Hg}, \mathrm{Fe}-\mathrm{As}, \mathrm{Pb}, \mathrm{Sb}, \mathrm{Cr}, \mathrm{W}$, $\mathrm{Ag}, \mathrm{Ni}$, in lodes and placers

Fe staining; placer $\mathrm{Au}$ in area

Uraniferous fluorite, $\mathrm{Cu}$, $S n$, and slightly radioactive accessory minerals in granite and placers

Barite veins

Quartz-pyrite veins

$\mathrm{Fe}, W, \mathrm{Au}, \mathrm{As}, \mathrm{Cu}, \mathrm{Sb}, \mathrm{Pb}$, Zn in 7odes. Rich Au Dist.
An early concentrate yielded $0.048 \%$ eu. Later on 1 y $0.002 \%$ ell found

Maximum eU $=0.005 \%$ from weathered granite

$\mathrm{eU}=0.005 \%$ in $\mathrm{Fe}$ stained schist

el $=0.007 \%$ in granite. Concentrates yielded up to $0.06 \%$ ell

Shate ytelded eu slightly under $0.05 \%$ estimated from counter reading

No anomalies detected in stream concentrates

General high background - up to 0.035 $\mathrm{Mr} / \mathrm{Hr}$

Placer concentrates had 0.002 up to $0.050 \%$ eU 
107 Chignik River Chignik Area, Alaska Peninsula

T08 Apollo and Sitka Mines, Unga Istand A laska Peninsula Region

109 Sand Point Area, Popof Island, Alaska Peninsula Region

110 Northwest Coast of Unga Island, Alaska Peninsula

Port Moller,

B-3 (not mapped on $1: 63$, 360)

$\omega$

'11) South Side Port Moller Bay and Stanjukovich Mt.

112 Port Moller Area, Alaska Peninsula

113 Red Top Mercury Mine.

Marsh Mt;

Aleknagik

Area

114 Lake Aleknagik B-3 A-2

Port Moller B-2

D-2 (not map-

ped on 1:63,

360)

D-2 (not map-

Dillingham

Dillingham
Chignik B-2, This report

Port Moller This report

This report

Andesite, dacite

gionerate, shale, coal.

Jurassic sandstone and conglomerate

Miocene andesite, dacite

Port Molier This report

Port Moller This report

ped 1:63,360)

This report
This report
Tertiary sandstone, shale coa]

coal, volcanic breccia, chert

Tertiary sandstone and volcanics; cretaceous sandstone, conglomerate, coal, limestone

Tertiary sandstone and volcanics

Cretaceous graywacke and siitstone

Cretaceous graywacke, argilitite, greenstone
Beach placer gold

$\mathrm{Au}, \mathrm{Fe}, \mathrm{Pb}, \mathrm{Zn}, \mathrm{Cu}$,
culated quartz veins

Coal

No significant

anomalies

No anomalies on mine dumps. Andesite had up to 3 to 4 times background count near shore

No anomalies

slight anomalies in chert boulders

Slight anomalies in Chignik sands tone and coa 1 - up to 3 times background

Black beach sands contain iron, zircon and traces of $\mathrm{Au}$

No anomalies

$\mathrm{Hg}$ in carbonate veins cutting siltstone

No anoma $7 j e s$

Small quartz and calcite veinlets
No anomalies 
115 Lake Iliamna Iljamna traverse along shoreline and C 207, TEI 557, vicinity
Paleozoic gneiss, schist, slate, chert, greenstone. Mesozoic and Tertiary lavas and tuffs, and granitic intrusives Iliamina Lake Area, on Silver Creek

117 Lake Clark, traverse a long shore- $B-2, B-4$

line and

vicinity

118 Kasna Creek clajms near Kantrashjbuna

Lake, Lake

Clark Area

319 Thompson Claims Kijik

River, Lake

Clark Area

120 Chistk Island Kenaj A-7, 81155
Lake Clark

A-4, A-5,

Lake Clark A-3

Lake Clark 8-3 A-8
Principally Cu; minor Ag. Mo, $\mathrm{Au}$, hematite, $\mathrm{Pb}, \mathrm{Zn}$ various prospects
Limestone and greenstone

Paleozoic gneiss and schist, Mesozoic Tavas, tuffs, metamorphics and intrusives

Limestone, lava, granite

$\mathrm{Cu}, \mathrm{Fe}$, in 1 imestone greenstone contact with calcite, epidote and quartz

Nearby prospects -- see 115 and 116

$\mathrm{Cu}$, hernatite in Jimestone

$\mathrm{Ag}-\mathrm{Pb}$ prospect; minor As-

Mesozoic granjte, lavas, and metamorphics

Jurassic shale and conglomerate (Naknek fin.) elf $=0.002 \%$ or 1 ess. Highly concentrated samples $=0.009 \%$ or less. Traces of sooty pitchb Tende found by USGS in con. centrates from beach sands near current creek

$\mathrm{eU}=0.000 \%$

$\mathrm{eU}=0.002 \%$ or less stream concentrates $0.007 \%$ eU or less

$\mathrm{eU}^{\mathrm{U}}=0.000 \%$

$\mathrm{eU}=0.002 \%$ or less

Airborne anomally not found on ground 
121 Mount Spurr Area-location

Tyonek (B-5?) C 202

indefinjte

122 Roundend and Tyonek D-2 Red Hill Bars, Kohfltna River Yentna District

Shalon Bar, Kahiltna

River Yentna

District

$A-2$
C 202, TEI 6

C 202 , TEI 6

Placer Au, Monzonite and thorianite in placer concentrates in gravels
124 Petersville area - Cache

Creek and

Peters Creek

drainages, Yentna Dist.

$\begin{array}{cl}\text { Talkeetna } & \text { C 202, TEI 6, } \\ \text { B-2, B-3 } & \text { B 1024-A } \\ & \text { (TEI 26) }\end{array}$

(TEI 26)
Mesozoic granjte; Tertiary lavas; Eocene sand and shales, coal

Plejstocene and Recent gravels

Pleistocene and Recent gravels

Coal?

Placer $\mathrm{Au}$ and $\mathrm{Pt}$

Tertiary shale, sandstone, $\mathrm{Au}$ and Pt placers and coal at lower eleva-

tions. Mesozoic metasediments exposed in mountain
Tuff and tuff breccia
Low grade $U$ along joints in tuffs over small areas
Concentrate in $0.0 \times \%$ ell range

Placer concentrates had up to $0.083 \%$ thorium and up to $0.190 \%$ el. Monzonite present

Placer concentrates yielded $0.237 \%$ et and $0.14 \% \mathrm{U}$ and $0.044 \%$ Th. (May be extremely concentrated)

el from placer concentrates up to $0.229 \%$ ej and $U$ content of $0.090 \%$ but later field investigations found a maximum el of $0.009 \%$ in stream concentrates. Highly radioactive samples may be extremely concentrated heavy fractions.

Further investigatjons on Kahiltna River, Poorman and Wi llow creek are recommended

$\mathrm{eU}=$ up to $0.027 \%$. A prospector reported one sample $=$ $0.29 \% \mathrm{U}$ 


\begin{tabular}{|c|c|c|c|c|c|c|}
\hline $\begin{array}{l}\text { Loc. } \\
\text { No. }\end{array}$ & $\begin{array}{l}\text { Locality } \\
\text { Name }\end{array}$ & Quadrang le & $\begin{array}{l}\text { Reference to } \\
\text { Radioactivity } \\
\text { Investigations }\end{array}$ & Country Rock & Mineralization & $\begin{array}{l}\text { Radioactivity } \\
\text { Measurement for } \\
\text { U Assay }\end{array}$ \\
\hline 126 & Owhat River & $\begin{array}{l}\text { Russian } \\
\text { Mission } C-1\end{array}$ & B 7155 & $\begin{array}{l}\text { Mafic igneous rock and } \\
\text { granite rubble }\end{array}$ & & $\begin{array}{l}\text { Ground traverses } \\
\text { showed } 0.009 \mathrm{Mr} \text { per } \\
\text { Hr. }\end{array}$ \\
\hline 727 & $\begin{array}{l}\text { Russian } \\
\text { Mountajns }\end{array}$ & $\begin{array}{l}\text { Russian } \\
\text { Mission C- }\end{array}$ & C 328 & $\begin{array}{l}\text { Felsic stock, mafic dikes, } \\
\text { Tertiary basait, cretac- } \\
\text { eous sediments }\end{array}$ & $\begin{array}{l}\text { Lodes with } \mathrm{As}, \mathrm{Cu} \text {, hematite } \\
\mathrm{Pb}, \mathrm{Zn} \text {; minor } \mathrm{Ag} \text {, Au and } \mathrm{Sn} \text {, } \\
\text { Trace of } \mathrm{U} \text { in metazeunerite } \\
\text { found on ore dump }\end{array}$ & eU up to $0.006 \%$ \\
\hline 128 & Marshal1 Area & MarshalT D-I & C 328 & $\begin{array}{l}\text { Carboniferous greenstone, } \\
\text { Cretaceous argili ite, } \\
\text { sandstone, quartzite } \\
\text { and conglonerate }\end{array}$ & $\begin{array}{l}\text { Placer Au; trace of Pt. } \\
\text { veins with Au, Fe, Pb, Mo, } \\
\text { near head of Willow Creek }\end{array}$ & $\mathrm{eU}=0.001 \%$ \\
\hline 129 & Julian Creek & Iditarod A-3 & $\begin{array}{l}\text { C 202, C 255, } \\
\text { TEI 45, Part I }\end{array}$ & $\begin{array}{l}\text { Cretaceous sandstone, } \\
\text { slate cut by granite } \\
\text { djkes }\end{array}$ & Placer Au & $\begin{array}{l}\text { concentrates }=0.03 \% \\
\text { (due to Th in mon- } \\
\text { azite) }\end{array}$ \\
\hline 131 & $\begin{array}{l}\text { Mcleod Moly- } \\
\text { bdenite pros- } \\
\text { pect, Kaiyuh } \\
\text { Mountains }\end{array}$ & Una lakeet B-1 & C 328 & $\begin{array}{l}\text { Precambrian or early Pale- } \\
\text { ozoic metamorphic rocks; } \\
\text { Cretaceous sandstone, } \\
\text { shale and conglomerate in } \\
\text { SW part, and granite } \\
\text { intrusives }\end{array}$ & Mo in quartz & $\begin{array}{l}\text { el up to } 0.003 \% \text { in } \\
\text { rhyolite porphry }\end{array}$ \\
\hline 132 & Nixon Fork & Medfra $A-4$ & C 202, C 279 & $\begin{array}{l}\text { Paleozoic limestone; } \\
\text { Cretaceous sandstone; } \\
\text { shale and slate; Ter- } \\
\text { tiary monzonite } \\
\text { intrusive }\end{array}$ & $\begin{array}{l}\text { Placer } \mathrm{Au} ; \mathrm{Au}, \mathrm{Cu}, \mathrm{Bi} \text { in } \\
\text { ] odes at jimestone } \\
\text { monzonite contact }\end{array}$ & $\begin{array}{l}\text { Limestone boulders at } \\
\text { Whalen mine contain } \\
\text { allanite and } 0.05 \% \\
\text { el due probably to } \\
\text { Th. concentrates } \\
\text { had up to } 0.078 \% \text {. } \\
\text { Uraninite and thor- } \\
\text { ianite ident1fied in } \\
\text { concentrates }\end{array}$ \\
\hline
\end{tabular}


133 Kantishna District

Mt. Mckinley

C 196 , TEM 235 $\mathrm{C}-2$

134 Mt. Eilson Area, Mt. McKinley Park
Mt. Mckintey
C 196, TEM 235

$\mathrm{B}-\mathrm{]}$

135 Poorman Placerville

area, Ruby-

Poorman Dist.

136 Flint Creek, Long Area, Ruby-Poorman District

137 Birch Creek, Ruby-Poorman District

Ruby A-5, A-6 C 202, TEI 6

Ruby $A-6, B-5, C 202$, TEI 6 B-6

Ruby $8-4$

C 279

Simjlar to 135

Devonian argillite, limestone, schist intruded by granodiorite

Paleozoic schist, greenstone, tuffs; minor Cretaceous sediments, lavas and granite

Similar to 135

Placer $A u$ and Sn

Placer Au

Placer $\mathrm{Au}$ and $\mathrm{Sn}$
Quartz fissure veins with

$\mathrm{Ag}, \mathrm{Pb}, \mathrm{Cu}, \mathrm{As}, \mathrm{Zn}, \mathrm{Fe}$.

Many old mines and prospects

$\mathrm{Cu}, \mathrm{Pb}, \mathrm{Zn}, \mathrm{Ag}$, as replacement in calcareous rock

138 Ruby Area, Ruby-Poorman

District

\section{T39 Melozitna} River, near mouth
Ruby

TEI 6

Ruby $D-5$, D-6

B 1155 (Yukon River traverse) congl onerate
Cretaceous sandstone and $\mathrm{e}\rfloor=0.001 \%$ or less

el less than $0.007 \%$

el up to $0.056 \%$ and U up to $0.020 \%$ from placer concentrates. Th up to $0.044 \%$

ell of crushed country rock 0.003 to

$0.008 \%$. Concentrates eU up to $1.63 \%$.

$(3,800: 1$ concentrated ratio)

Crushed granjte had up to $0.006 \%$ eU; concentrates had up to $0.36 \%$ el (concentration ratio 2,700:1)

$\mathrm{eU}=0.00 \%$

Cretaceous grit in Mejozitna Canyon gave $0.017 \%$ el and a panned concentrate of $0.70 \%$ eU 
Reference to

$\begin{array}{lll}\text { Loc. Locality } & \text { Name } & \text { Radioactivity } \\ \text { No. _ } \quad \text { Nadrangle } & \text { Investigations }\end{array}$

140 Yukon River Traverse, Ft. Beaver, LivYukon to Ruby engood, Tanana, Ruby

141 Tofty Tin Belt Tanana A-2 Manley Hot

Springs Dist.
C 202, C 317 TEI 6

\section{B 1155}

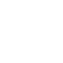

Paleozoic and Mesozoic sediments, greenstone, metamorphic rocks and granite

Cretaceous phyllite and graywacke. Tertjary granite nearby

$\stackrel{+}{\stackrel{8}{0}}$

142 Hot Springs
Dome, Manley Hot Springs

District

143 Roughtop Mt. - Tanana A-2 Boulder Creek Area, Man]ey Hot Springs

District

144 Eureka Area, Manley Hot Springs-Ramipart Dist.
Tanana A-2 C 202, C 377

Certiary granite, Cretaceous metamorphic rocks

Tertiary granite, Cretaceous metamorphic rocks

Cretaceous metamorphic on Elephant Mountain rocks, quartz monzonite
Placer Au and Sn; Chromite reported in area. The 5 following radioactive minera]s were identified in placer concentrates: ellsworthite, exchynite, columbite, monazite, zircon

Pb-Ag veins

Placer Au
Radioactivity

Measurement or U Assay

Stream concentrates yielded up to $0.015 \%$ el ; Cretaceous rocks had up to $0.003 \%$ els; Tertiary conglomerates yjelded between $0.014 \%$ eU upstream from Rampart. Paleozoic intrusives had up to $0.008 \% \mathrm{eU}$

Highly concentrated placer material yielded up to 2.3\% eU in one sample; others were $0.035 \%$ $\mathrm{eU}$ or less

Granite had an average eU of $0.003 \%$

01d report states a local resident found stream pebbles which assayed $0.21 \%$ el but material not found by U.S.G.S. No anoma]jes located

elt of quartz monzonite $=0.004 \%$; ell of placer concentrates $=0.004$ to $0.042 \%$. Radioactivity due to monazite 
145 Rampart Area Tanana B-T, C-1

Solomon, west C 300, C 202 half

Seward

Peninsula

147 Big Hurrah

Solomion C-5 C 196

Mine, Seward

Peninsula

$\dot{+}$

$\pi 48$

Eagle) anti-

mony prospect

Seward Penin-

sula

149 Cape None Area Nome B-], C-1 C 202, C 244

Seward Solomon $B-6$,

Peninsula

C-6

150 Road Traverses Soloman-Nome, C 196 Nome Area

151 Hed and Strand Nome D-1

Mine, Nome

District
Mountain core is principally pre-Cretaceous granites and undivided igneous rocks; bordering rocks are schist, greenstone, and various metamorphic rocks, Precambrian to Tertiary in ages

Carboniferous black s]ate $\mathrm{Au}, \mathrm{Cu}, \mathrm{Sb}$, pyrrhotite intruded by quartz vein

Quartz veins in Carboniferous slate

$\mathrm{Sb}$

No significant lode deposits but one $\mathrm{Ag}-\mathrm{Pb}$ prospect was worked. Coal is present. one Au placer mine. Radioactivity found in accessory minerals associated with granite

Complex of granjte, gneiss schist, greenstone of Paleozolc to Mesozoic ages

Schist, granite, grave1s, So, pyrite, arsenopyrite limestone, slate

Early Paleozoic schist
Quartz veins, Sb, pyrite, arsenopyrite
eU from placer concentrates $=0.001 \mathrm{tc}$ $0.010 \%$, probably due to zircon. Bed of lignite has ell of $0.001 \%$

Many samples of stream concentrates tested. Highest eU in Clear Creek area where concentrates yielded up to $0.104 \%$ eU. Most concentrates had el in $0.0 \times$ range

eU under $0.001 \%$

el under $0.001 \%$

eU of concentrates of crushed rock = 0.001 to $0.012 \%$ and slope wash concentrates had el from 0.006 to $0.025 \%$

No important anomalies detected

$\mathrm{eU}=0.001 \%$ 
158 Potato Mt Area, York Dist. Seward Peninsula

159 Ear Mt. , York Dist., Seward PeninsuTa

Tel]er $\mathrm{C}-4$

Serpentine-

Bende leben Kougarok Area C-6, D-6

Seward

Peninsula

C 265, TEI 6 C 202, B 1024-C TEI 6

C 196

Early Paleozoic black slate intruded by granite porphyry dikes and quartz veins of Mesozoic age

Scinistose limestone, shale Primarily Sn prospects; slate, quartzite. Granite traces of $\mathrm{Cu}, \mathrm{Au}, \mathrm{Pb}, \mathrm{Zn}$. gabbro, alaskite dikes

Sn, fluorite, in veins and placers

Most of the radioactivity granite and in quartzDarby Mt., Seward

Peninsula

\section{Sweepstakes}

Creek and

vicinjty,

eastcentra?

Seward Peninsula
Solomon D-1 C 202, C 300

Candle B-5

C 250
Early Paleozoic limestone slate and schist; Paleozoic greenstone, Mesozoic-Tertiary granite and other felsic intrusives

Granites, greenstone, schist of pre-Cretaceous ages

Placer and lode Au; minor placer $\mathrm{Sn} ; \mathrm{Cu}, W$, Hg prospect

Placer $\mathrm{Au}, \mathrm{Cu}, \mathrm{Ag}-\mathrm{Pb}$ lode prospects, coal. Radjoactivity due to hematite, altanite, zircon, sphene

Pre-Cretaceous syenite and lavas; Tertiary basalt found was in margins of tourma $T$ ine veins and with red hematte

Less than $0.007 \%$ eU

Strean concentrates yjelded up to $1.0 \%$ el in heavy mineral fraction. Average for a]1 concentrates collected was $0.031 \%$ ell. Radioactivity believed due to monazite and zircon. One piece of ore had $0.182 \%$ ell

Average el of 29 samples of graptte $=0.008 \%$ and their heavy metals portion average $0.034 \%$. Highest radioactivity was found in vicinity of Hot Springs $\mathrm{Cr}$. Maximum eU of crushec granite $=0.032 \%$

41 stream concentrate samples had an el between 0.01 and $0.02 \%$ and the max $1-$ mum el was $0.01 \%$

Placer Au; minor placer Pt.
On $7 y$ noticeable radioactivity in bedrock was in syenite which had el from 0.001 to $0.013 \%$ in crushed samples; stream gravels eU content $=0.0001 \%$ 


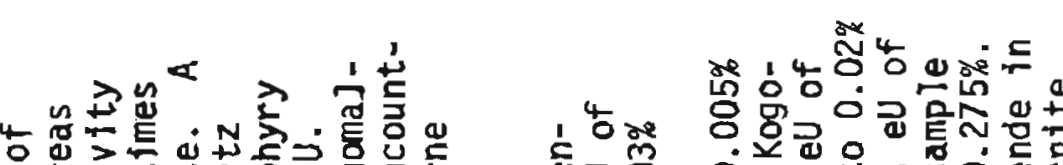

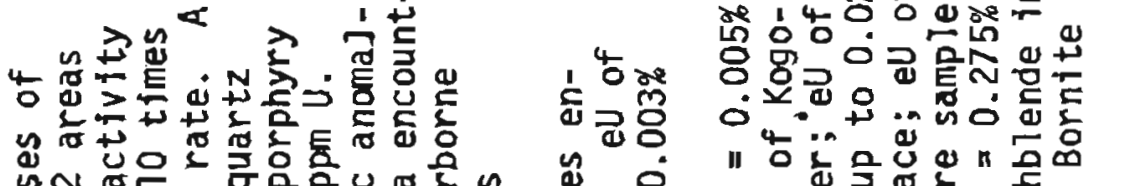

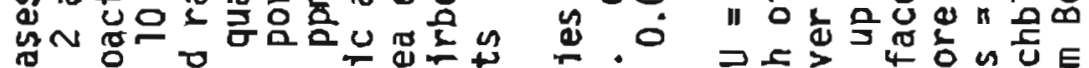

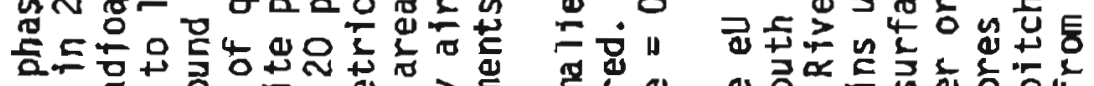

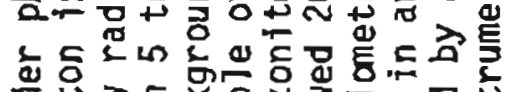

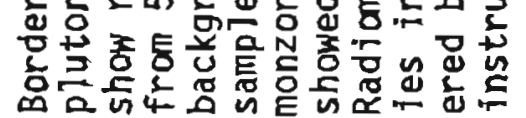

\section{造}

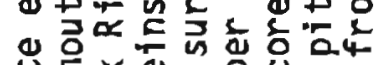

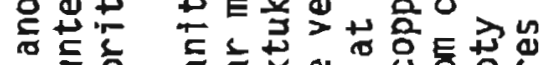

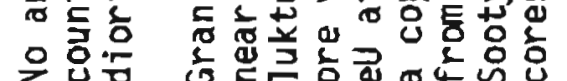

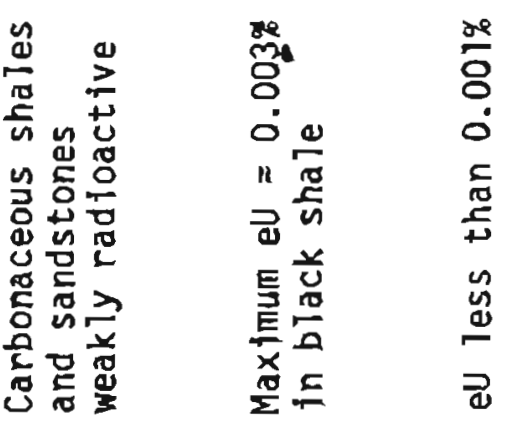

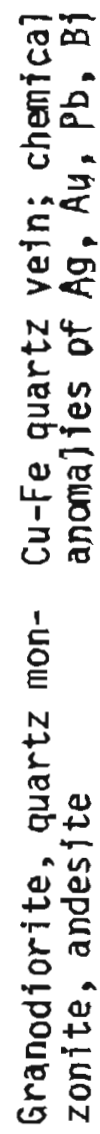

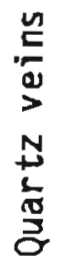
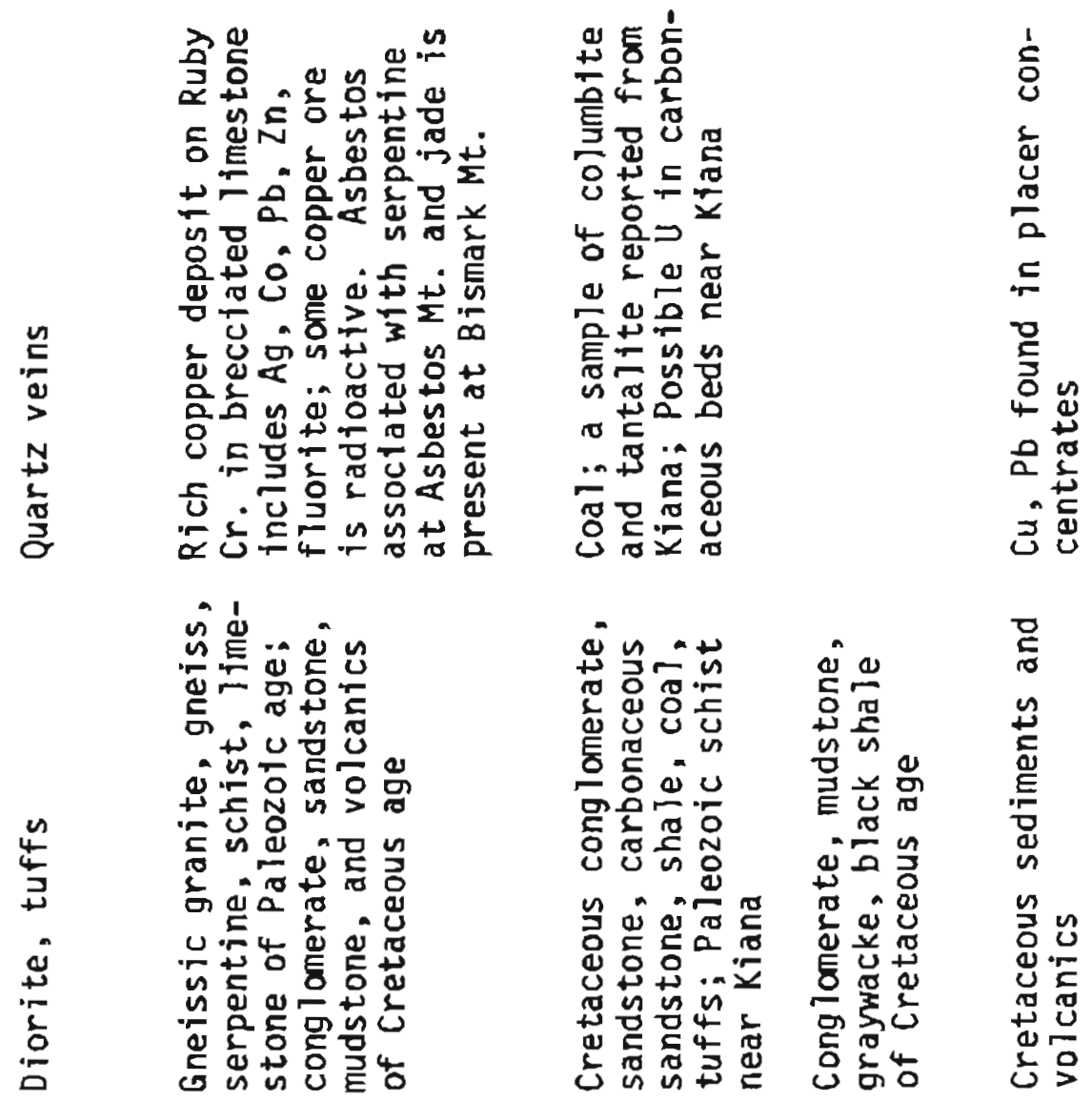

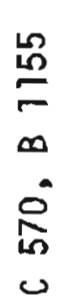

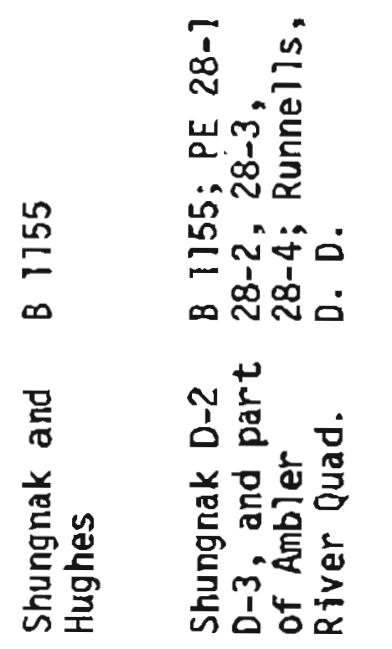

范导出

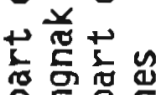

岀총조옴

\section{的被}

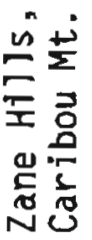

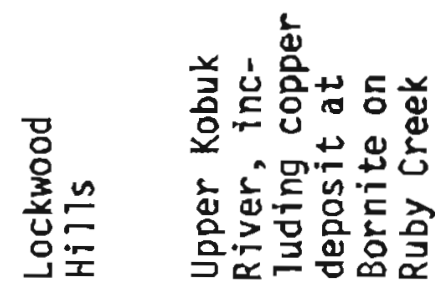

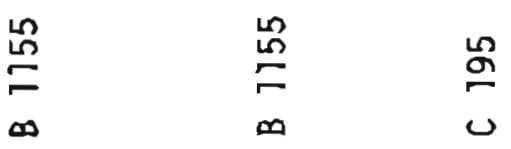

ำ

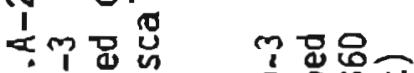

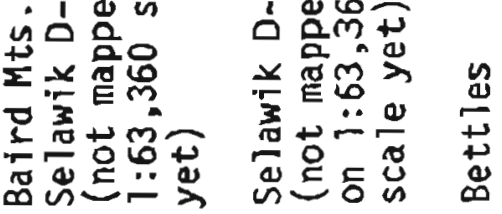

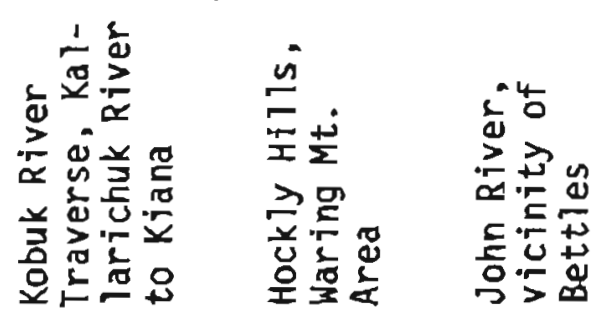




\begin{tabular}{|c|c|c|c|c|c|c|}
\hline $\begin{array}{l}\text { Loc. } \\
\text { No. }\end{array}$ & $\begin{array}{c}\text { Locality } \\
\text { Name }\end{array}$ & Quadrang le & $\begin{array}{l}\text { References to } \\
\text { Radioactivity } \\
\text { Investigatjons }\end{array}$ & Country Rock & Mineralization & $\begin{array}{c}\text { Radioactivity } \\
\text { Measurement or } \\
\text { U Assay }\end{array}$ \\
\hline 174 & $\begin{array}{l}\text { Gold Bench, } \\
\text { So. Fork } \\
\text { Koyukuk } \\
\text { River, Wise- } \\
\text { man Dist. }\end{array}$ & Bettles & C 195, C 202 & Mesozoic volcanics & $\begin{array}{l}\text { Placer Au, hematite and } \\
\text { metallic sulfides in placer } \\
\text { concentrates }\end{array}$ & $\begin{array}{l}\text { el of piacer concen- } \\
\text { trates }=0.027 \% \\
\text { maximum; probably } \\
\text { due to trace of } \\
\text { thorianite }\end{array}$ \\
\hline 175 & $\begin{array}{l}\text { Wiseman Dist. } \\
\text { Middle Fork } \\
\text { Koyukuk River, } \\
6-10 \text { miles So. } \\
\text { of Wiseman }\end{array}$ & Wiseman & MI 30-1 & $\begin{array}{l}\text { Birch Creek schist and } \\
\text { nearby granite intrusives }\end{array}$ & & $\begin{array}{l}\text { No anoma lies detect- } \\
\text { ed in stream concen- } \\
\text { trates or schist } \\
\text { bedrock }\end{array}$ \\
\hline $\begin{array}{l}176 \\
1 \\
\text { o } \\
1\end{array}$ & $\begin{array}{l}\text { Wiseman Dist. } \\
\text { Nolan Creek }\end{array}$ & Wiseman & C 195 & $\begin{array}{l}\text { Birch Creek schist and } \\
\text { nearby granite intrusives }\end{array}$ & Placer Au & $\begin{array}{l}\text { eU of placer con- } \\
\text { centrates under } \\
0.007 \%\end{array}$ \\
\hline 177 & $\begin{array}{l}\text { Wiseman Dist. } \\
\text { Rye Creek }\end{array}$ & Wiseman & C 195 & Birch Creek schist & Placer Au & $\begin{array}{l}2 \text { placer concentrate } \\
\text { samples had el of } \\
0.014 \%\end{array}$ \\
\hline 178 & $\begin{array}{l}\text { Tiglukpuk Cr. } \\
\text { Mo. side of } \\
\text { Brooks Range }\end{array}$ & Chandier Lake & PP 302-A & $\begin{array}{l}\text { Mississippian Lisburne } \\
\text { group consisting of mud- } \\
\text { stone, limestone, dolanite } \\
\text { chert and phosphate rock }\end{array}$ & $\begin{array}{l}\text { Phosphate rock; the highest } \\
\text { the } \mathrm{P}_{2} \mathrm{O}_{5} \text { contents contain } \\
\text { the highest eU. } \mathrm{P}_{2} \mathrm{O}_{5} \\
\text { assays up to } 34.0 \%\end{array}$ & $\begin{array}{l}\text { eU up to } 0.021 \% \text { in } \\
\text { phosphate rock }\end{array}$ \\
\hline 179 & $\begin{array}{l}\text { Upper Kiruk- } \\
\text { tagiak River, } \\
\text { No. side of } \\
\text { Brooks Range }\end{array}$ & Chandier Lake & PP 302-A & As above & As above & $\begin{array}{l}\text { ef up to } 0.022 \% \text { in } \\
\text { phosphate rock }\end{array}$ \\
\hline
\end{tabular}


U. S. GEOLOGICAL SURVEY CIRCULARS

Circular 184: Moxham, R. M. and Nelson, A. E., 1952, Reconnaissance for radioactive materials in south-central Alaska, 36 p., 1 pl., 4 figs

Circular 185: White, M. G., 1962, Reconnaissance for radioactive deposits along the upper Porcupine and lower Coleen Rivers, northeastern Alaska, 13 p., 3 figs

Circular 195: White, M. G., 1952, Radioactivity of selected rocks and piacer concentrates from northeastern Alaska, 12 p., 5 figs

Circuiar 196: White, M. G., West, W. S., Tolbert, G. E., Nelson, A. E., and Houston, J. R., 1952, Preliminary report of reconnaissance for uranium in Alaska, 1951, 17 p., 4 figs

Circular 202: Bates, Robert G. and Wedow, Helmuth, Jr., 1953, Preliminary summary review of thorium-bearing mineral occurrences in Alaska, $13 \mathrm{p} ., \mathrm{I}$ fig

Circular 207: Moxham, R. M. and Nelson, A. E., 1952, Reconnaissance for radioactive deposits in the southern Cook Inlet region, Alaska, 1949, 7 p., 1 fig

Circular 214: West, W. S. and White, M. G., 1952, The occurrence of zeunerite at Brooks Mountain, Seward Peninsula, Alaska, 7 p., 1 pl., $1 \mathrm{fig}$

Circular 244: White, M. G., West, W. S., and Matzko, J. J., 1953, Reconnaissance for radioactive deposits in the vicinity of Teller and Cape Nome, Seward Peninsula, Alaska, $1946-47,8$ p., 2 pls

Circular 248: Wedow, Helmuth, Jr, and others, 1953, Preliminary summary of reconnaissance for uranium and thorium in Alaska, 1952, 15 p., 1 pl., 1 fig

Circular 250: Gault, H. R., Killeen, P. L., West, W. S. and others, 1953, Reconnaissance for radioactive deposits in the northeastern part of the Seward Peninsula, Alaska, 1945-47 and 1951, 31 p., 3 pls., 4 figs

Circular 255: White, M. G. and Killeen, P. L., 1953, Reconnaissance for radioactive deposits in the lower Yukon-Kuskokwim highlands region, Alaska, 18 p., 4 figs

Circular 265: Moxham, R. M. and West, W. S., 1953, Radioactivity investigations in the Serpentine-Kougarok area, Seward Peninsula, Alaska, 17 0., 2 figs

Circular 279: White, M. G. and Stephens, J. M., 1953, Reconnaissance for radioactive deposits in the Ruby-Poorman and Nixon Fork districts, west-central Alaska, 19 p., 4 figs

Circular 300: West, W. S., 1953, Reconnaissance for radioactive deposits in the Derby Mountains, Seward Peninsula, 1948, 7 p., 1 pl.

Circular 316: Wedow, Helmuth, Jr., 1954, Reconnaissance for radjoactive deposits in the Eagle-Nation area, east-central Alaska, 1948, 9 p., 1 pl., 1 fig

Circular 317: Moxham, R. M., 1954, Reconnaissance for radioactive deposits in the Manley Hot Springs - Rampart district, east-central Alaska, 1948, 6 p., 2 figs

Circular 319: White, M. G., and West, W. S., 1953, Reconnaissance for uranjum in the lost River area, Seward Peninsula, Alaska, 1951, 4 p., 1 fig 
Circular 328: West, W. S., 1954, Reconnaissance for radjoactive deposits in the lower Yukon-Kuskokwin region, Alaska, 1952, 10 p., 2 pls., 2 figs

Circular 331: Wedow, Helmuth, Jr. and others, 1954, Reconnaissance for radioactive deposits in eastern interior Alaska, 1946, 36 p., 11 figs

Circular 335: Wedow, Helmuth, Jr., White, M. G., and others, 1954, Reconnaissance for radioactive materials in east-central Alaska, 1949, 22 p., 2 pls., 6 figs

Circular 348: Nelson, A. E., West, W. S., and Matzko, J. J., 1954, Reconnaissance for radioactive materials in eastern Alaska, 1952,21 p., 6 figs

Circular 570: Miller, Thomas P., and Ferrians, Oscar J., Jr., 1968, Suggested areas for prospecting in the central Koyukuk River region, Alaska.

\section{U. S. GEOLOGICAL SURVEY BULLETINS}

Bulletin 1024-A: Robinson, G. D., Wedow, Helmuth, Jr., and Lyons, J. B., 1955, Radioactivity investigations in the Cache Creek area, Yentna district, Alaska, 1945, 23 p., 6 p1s., 4 figs

Bulletin 1024-B: West, W. S. and Benson, P. D., 1955, Investigations for radioactive deposits in southeastern Alaska, 33 p., 3 pls., $1 \mathrm{fig}$

Bulletin 1024-C: Killeen, P. L. and Ordway, R. J., 1955, Radioactivity investigations at Ear Mountain, Seward Peninsula, Alaska, 1945, 36 p., 2 pls., 7 fig

Bulletin 1058-A: Houston, J. R., Bates, R. G., Velikanje, R. S., and Wedow, Helmuth, Jr., 1958, Reconnaissance for radioactive deposits in southeastern Alaska, 1952, 31 p., 3 pls., 4 figs

Bulletin 1154: Mackevett, E. M., Jr., 1963, Geology and ore deposits of the Bokan Mountain uranium-thorium area, southeastern Alaska, 125 p., 5 pls., 25 figs

Bulletin 1155: Contribution to Economic Geology of Alaska, 1963, $89 \mathrm{p}$.

\section{U. S. GEOLOGICAL SURVEY PROFESSIONAL PAPERS}

Professional Paper 302 A: Patton, William W., Jr., and Matzko, John J., 1959, Phosphate deposits in Northern Alaska

\section{U. S. GEOLOGICAL SURVEY TRACE ELEMENTS INYESTIGATIONS}

Trace Elements Investigation Report No. 6: Harder, James D., and Reed, John E., 1945, Preliminary report on radioactivity of some Alaskan placer samples

Trace Elements Investigation Report 45, Part 1: White, M. G., and Killeen, P. L., 1950, Radioactivity and mineralogy of concentrates from the placers of Julian, Moore, and Candle Creeks, and the Cripple Creek Mountains, Lower Yukon-Kuskokwim Highlands region, Alaska

Trace Elements Investigation Report 577: Wedow, Helmuth, Jr., 1956, Summary of reconnaissance for radioactive deposits in Alaska, 1945-7954, and an appraisal of Alaskan uranium possibilities 


\section{U. S. GEOLOGICAL SURVEY TRACE ELEMENTS MEMORANDUMS}

Trace Elements Memorandum Report 235: Wedow, Heimuth, White, Max G., and Moxham, Robert M., 1951, Interim report on an appraisa? of the uranium possibilities of Alaska

Trace Elements Memorandum Report 319: Tolbert, G. E., and Neison, A. E., 1951, Preliminary summary of reconnaissance for uranjum in the Alaska Railroad-Iliamna Region during 1951.

Trace Elements Memorandum Report 330: Moxham, Robert M., and West, Walter S., 1953, A radiometric traverse along the Alaska Railroad

Trace Elements Memorandum Report 356: Houston, Jaseph E., 3952, Interim report on the radioactive carbonate-hematite veins near Salmon Bay, Prince of Wales Island, Southeastern Alaska

\section{MISCELLANEOUS U. S. GEOLOGICAL SURVEY PUBLICATIONS}

Open File Report 280: Mackevett, E. M., Jr., Brew, David A., Kawley, C. C., Huff, Lyman C., and Smith, James G., 1967, Mineral resources of Glacier Bay Natjonal Monument, Alaska

Map I 530: Patton, William W., and Miller, Thomas P., 1968, Regional geologic map of the Selawik and Southeastern Baird Mountains quadrangles, Alaska

\section{TERRITORY OF ALASKA DEPARTMENT OF MINES REPORTS}

IR: Fowler, H. M., 1948, (July 36-18) Wacker claims

IR: Fowler, H. M., 1949 (June 14, 29) Mountain View property, Hyder District

IR: Williams, James A., Sept 20, 1952, Salmon Bay Area

MI 30-1: Saunders, Robert $H$., 7954, Radioactive mineral investigation near Wiseman

MI 44-2: Sandvik, Peter 0., 1956, Candle uranium driling, Northeast Seward Peninsula

MR 195-23: Joesting, H. R., 1941, 1942, 1943, Strategic materja1s in Alaska

MR 195-24: Joesting, H. R., 1943, Tests on radioactive rocks

PE 28-1: Saundens, Robert H., 1952, Berg copper prospect (Ruby Creek)

PE 28-2: Saunders, Robert H., 1955, Berg copper prospect (Ruby Creek)

PE 28-3: Saunders, Robert H., 1956, Berg copper prospect (Ruby Creek)

PE 28-4: Saunders, Robert H., 1962, Bear Creek prospect;

Saunders, Robert H., 1952, 1955, 1956, Berg prospect (Ruby Creek)

PE 45-1: Jones, Daniel A., Peace river uranium prospect, Seward Peninsula

PE 51-1: Williams, James A., 1951, Connell property, 28 mile Yukon River, Radiometric Investigation 
PE 115-7: Willtams, James A., 1955, BBH property (Endicott Arm)

PE 120-9: Roehm, J. C., 1942, Mahoney Mine, George Inlet

PE 120-11: Williams, James A., 1952, Mountain View property, Hyder district

PE 120-14: Williams, James A., 1956, Black Jack No. 7 claim

PE 121-5: Williams, James A., 1955, I and L Property (Kendrick Bay)

PE 121-6: Wi11iams, James A., 1955, Lazo property (Moira sound)

PE 121-7: Williams, James A., 1955, Carol Ann property (Kendrick Bay)

\section{OTHER REFERENCES CITED}

Barns, F. F., Wahrhaftig, C. A., Hickcox, Jacob Freedman and Hopkins, D. M., 1951, Coal investigations in South-centra] Alaska, 1944-46; U. S. Geo1. Survey Bul1. 963-E

Mertie, J. B., Jr., 1942, Tertiary deposits of the Eagle-Circle district, Alaska, U. S. Geol. Survey Bull. 917-9

Runnel1s, Donald D., 1964, The copper deposits of Ruby Creek, Cosmos Hills, Alaska; A thesis, Marvard University, Cambridge, Mass., May 1963 